doi: 10.32620/oikit.2019.85.01

УДК 629.7.01

О. Г. Гребеніков, О. Д. Донець*, С. В. Трубаєв, А. С. Чумак

\title{
Метод загального проектування регіональних пасажирських літаків
}

\author{
Національний аерокосмічний університет ім. М. Є. Жуковського «XAl», \\ *Державне підприємство «Антонов»
}

\begin{abstract}
Запропоновано метод загального проектування регіональних пасажирських літаків, призначених для перевезення пасажирів, багажу, пошти та вантажів на внутрішніх i міжнародних авіалініях з можливістю експлуатації на аеродромах зі штучним покриттям і підготовлених ґрунтових злітно-посадкових смугах. Літак розроблено для заміни застарілого пасажирського літака Ту-134 у парку авіакомпаній СНД та інших країн. Розроблено концепцію створення літака із застосуванням систем інтегрованого проектування. Ураховано вплив параметрів літака на аеродинамічні й масові характеристики за умови забезпечення вимог авіаційних правил (АП) до компонування i безпеки польотів. Визначено діапазон зміни параметрів модифікацій літака. Метод апробовано шляхом порівняння визначених параметрів і параметрів регіональних пасажирських літаків ДП «АНТОНОВ».

Літак характеризується сучасною аеродинамічною конфігурацією, застосуванням економічних двигунів. Сучасне пілотажно-навігаційне обладнання й обладнання радіозв'язку, застосування багатофункціональних індикаторів, електродистанційної системи керування польотом дають змогу застосовувати його на будь-яких повітряних трасах, у простих і складних метеоумовах, удень і вночі, а також на маршрутах 3 високою інтенсивністю польотів при високому рівні комфорту екіпажу.

Комфорт пасажирів - на рівні середньостатистичного комфорту на магістральних літаках, що забезпечується раціональним компонуванням і складом сервісних приміщень, глибокою ергономічною оптимізацією загального та індивідуального простору пасажирського салону. Літак повністю відповідає нормам льотної придатності АП-25.
\end{abstract}

Основні технічні характеристики літака за величиною $\epsilon$ близькими до характеристик літаків-аналогів фрірм Embraer і Bombardier. Крім того, літак має такі переваги: можливість експлуатації на аеродромах з малопідготовленими і ґрунтовими ЗПС, наявність дверей-трапа, висока захищеність двигунів від пошкодження сторонніми предметами, високий рівень комфорту пасажирів, наявність великих багажних полиць, висока ефективність експлуатації, цим забезпечується високий рівень конкурентоспроможності літака на світовому ринку

Ключові слова: літак; проектування; загальний вигляд; компонування; параметри; майстер-геометрія; фрюзеляж; розрахунок маси; аеродинамічна якість; транспортна ефективність; параметрична модель.

Опубліковані результати досліджень тенденцій і перспектив розвитку світового цивільного літакобудування прогнозують подальше збільшення обсягів авіаперевезень і потреб світового ринку в нових пасажирських авіалайнерах [1] . Вітчизняний ринок пасажирських авіаперевезень потребує (близько 50 літаків на рік [2]) в заміни морально й фрізично застарілих літаків типу Ту-134, призначених для перевезення 75 - 85 пасажирів, багажу, пошти і вантажів з діапазоном практичної дальності 2500...5000 км. При цьому новий літак має бути здатним до модифікації і збільшення пасажиромісткості. Згідно 3 даними Bombardier [3], потреба в нових регіональних літаках у 2007 - 2027 рр. складе 11000 одиниць, близько 53 \% з яких - літаки на 100 - 149 місць, а 37 \% - 
на 60 - 99 місць, при цьому авіакомпанії насамперед зацікавлені у зниженні експлуатаційних витрат.

Метою загального проектування нового регіонального пасажирського літака $€$ створення конструкції з характеристиками, що забезпечують більш ефективне виконання традиційних завдань або нових, які не можуть бути вирішені іншими способами.

Для проектування регіонального пасажирського літака розробляють технічне завдання. Згідно йому літак створюється як база ряду пасажирських літаків пасажиромісткістю до 100 чоловік з двома двоконтурними реактивними двигунами з високим ступенем конструктивно-технологічної та експлуатаційної наступності та уніфікації 3 літаками, виробленими на вітчизняних авіабудівельних підприємствах. Літаки цього ряду мають забезпечити:

- відповідність вимогам норм льотної придатності АП-25, FAR-25, CS-25:

- надійність і безпеку польотів;

- екологічні характеристики (нормовані рівні шуму в пасажирських салонах і на місцевості, рівень шкідливих викидів) що впливають на навколишнє середовище;

- високий рівень комфорту;

- економічність в експлуатації.

Технічне завдання містить конкретні вимоги до його характеристик та умов експлуатації літака, що $є$ конкурентоспроможним.

Основні льотно-технічні характеристики базового літака

Кількість пасажирів, чол.

Максимальна маса платного навантаження, т

Двигун:

- тип

- кількість

ТРДД

Швидкість, км/ год.:

- максимальна

- максимальної дальності

$\sim 870$

Крейсерська висота, км:

$\sim 820$

Практична дальність, км:

$11-12$

- з максимальним платним навантаженням

- з пасажирами

- без вантажу і пасажирів

ВПП (сухий бетон, Н=0, СА), м

Склад екіпажу, чол.:

- командир ВС

- другий пілот

- 2 бортпровідники

Ресурси і терміни служби

Проектний ресурс Проектний термін служби

Паливна ефрективність

Технічний рівень

$$
\begin{array}{r}
\sim 2500 \\
\sim 4500 \\
\sim 5500 \\
1500 \ldots 1800 \\
1 \\
1
\end{array}
$$

За необхідності

Вагова ефективність

Питома трудомісткість технічного обслуговування

Річний наліт
$24,9+2 \%$ грам палива на 1 пас.-км $284+2 \%$ кг порожнього спорядженого літака на 1 пасажира

$$
\text { 2,5 люд.-год. на } 1 \text { год нальоту }
$$
$2800 \ldots 3500$ год 
Очікувані умови експлуатації та експлуатаційні фрактори

Барометричний тиск у всьому діапазоні висот польоту

Температура зовнішнього повітря $t_{\text {зп }}$

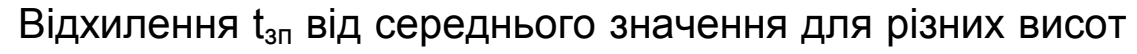
по лініях

Масова щільність, барометричний тиск, в'язкість повітря Температура зовнішнього повітря біля землі

Відносна вологість зовнішнього повітря у землі при $\mathrm{t}_{3 п} 35^{\circ} \mathrm{C}$

Напрямок та швидкість вітру у землі:

- зустрічна складова

- попутна складова

- бічна складова під кутом $90^{\circ}$ до 3ПС:

$$
\mathrm{f} \geq 0,5
$$

$f \geq 0,3$

Літак повинен експлуатуватися на аеродромах з бетонним і нежорстким укріпленим покриттями (асфральтобетон, в зв'язаному стані галька або гравій, укочений грунт), підготовлених відповідно до НАС ГА (НАС ГА-86).

Висота розташування аеродрому

Над рівнем моря

Нижче рівня моря

Допустимі стани ЗПС (згідно НАС ГА-86):

- $\quad$ суха; волога;

- $\quad$ мокра з ділянками води;

- $\quad$ залита водою до 10 мм;

- $\quad$ покрита шаром сльоти до 15 мм; засніжена з $f \geq 0,3$.

Літак повинен забезпечувати польоти:

- $\quad$ за правилами візуального польоту й польоту за приладами;

- $\quad$ удень і вночі;

- $\quad$ у простих і складних метеоумовах;

- $\quad$ в умовах обмерзання (з $\mathrm{t}_{\text {зп }}$ не нижче мінус $\left.30{ }^{\circ} \mathrm{C}\right)$;

- $\quad$ по внутрішніх та міжнародних повітряних трасах і лініях;

- $\quad$ над рівнинною, горбистою і гірською місцевістю;

- $\quad$ над водними просторами, безорієнтирною місцевістю і в діапазоні географрічних широт до $73^{\circ}$ північної і $55^{\circ}$ південної.

Експлуатаційні мінімуми погоди:

- $\quad$ для зльоту - дальність видимості на ЗПС не менше 200 м;

- $\quad$ для посадки - II категорія ICAO з можливістю доведення до категорії III A ICAO, за умови складу і характеристик наземних засобів забезпечення польоту відповідно до НПП ГА 3 урахуванням існуючих і перспективних засобів забезпечення навігації і комунікації.

Під час розроблення концепції створення літака виконано аналіз статистичних даних щодо літаків аналогів. Як найближчи аналоги розглянуто літаки таких типів: Ty-134, ERJ 170LR, ERJ 175LR, CRJ 700LR, CRJ 705ER (рисунок 1, таблиця 1). 

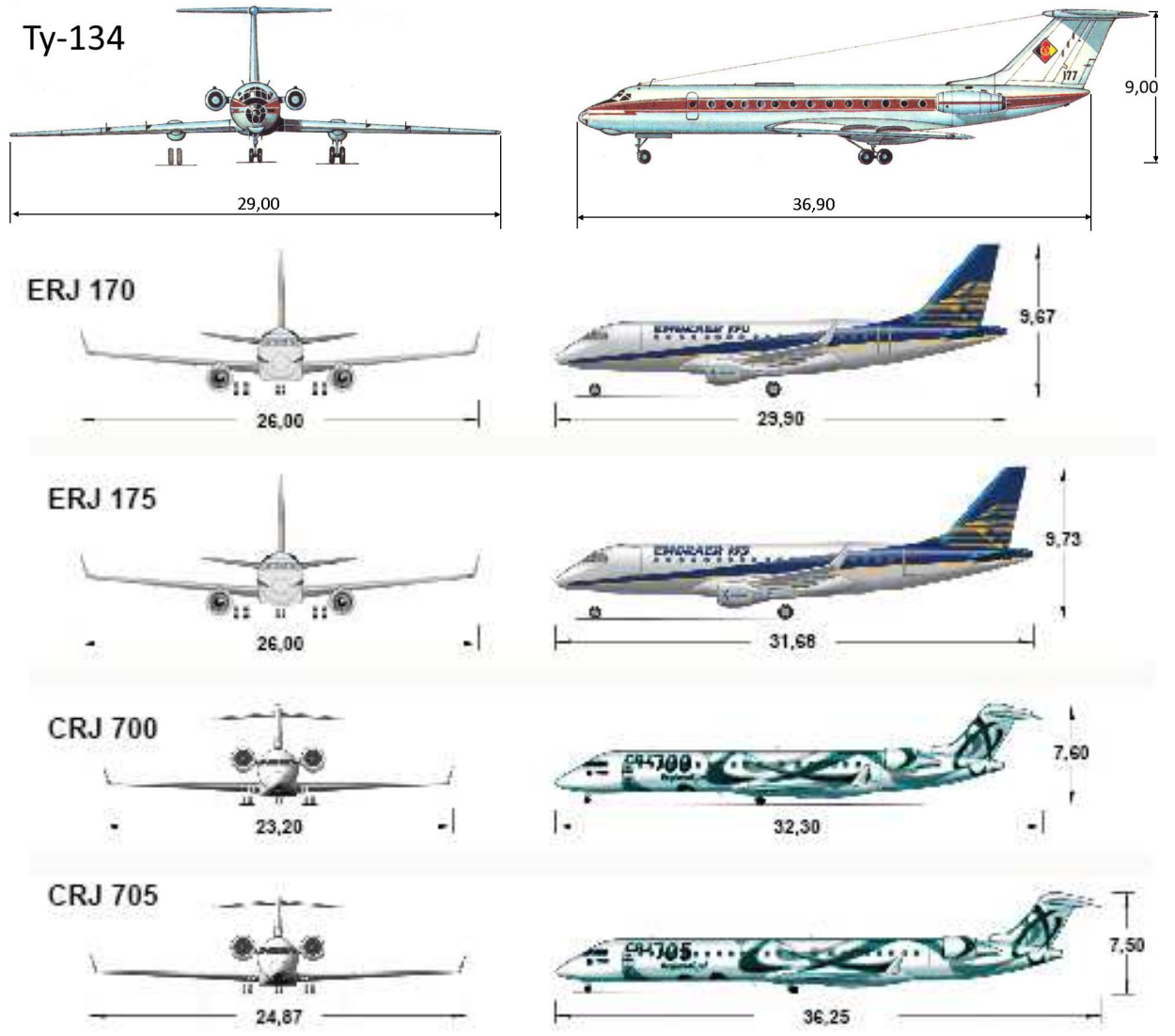

Рисунок 1 - Схеми літаків аналогів

Таблиця 1 - Статистичні дані щодо літаків

\begin{tabular}{|c|c|c|c|c|c|c|}
\hline Літак & Ty-134 & ERJ170 & ERJ175 & CRJ700 & CRJ705 & Проект \\
\hline $\begin{array}{l}\text { Максимальна } \\
\text { злітна вага, т }\end{array}$ & 47,6 & 37,2 & 38,79 & 34,93 & 37,42 & \\
\hline $\begin{array}{l}\text { Пасажиромісткість, } \\
\text { чол. }\end{array}$ & 76 & 70 & 78 & 70 & 74 & $73-99$ \\
\hline Тип двигуна & Д-30 & CF34-8E5 & CF34-8E5 & CF34-8C5 & CF34-8C5 & ТРДД \\
\hline Максимальна тяга, тс & 6,8 & 6,44 & 6,44 & 6,26 & 6,58 & \\
\hline $\begin{array}{l}\text { Максимальна } \\
\text { крейсерська } \\
\text { швидкість, км/год. } \\
\end{array}$ & 870 & 870 & 870 & 876 & 880 & $\sim 870$ \\
\hline $\begin{array}{l}\text { Максимальна } \\
\text { крейсерська висота, } \\
\text { км }\end{array}$ & 12,0 & 12,5 & 12,5 & 12,5 & 12,5 & $\sim 12,0$ \\
\hline $\begin{array}{l}\text { Дальність польоту, } \\
\text { км: } \\
\text { з пасажирами } \\
\text { максимальна }\end{array}$ & $\begin{array}{l}2400 \\
3800\end{array}$ & $\begin{array}{l}3411 \\
4480 \\
\end{array}$ & $\begin{array}{l}3175 \\
4300 \\
\end{array}$ & $\begin{array}{l}3408 \\
4900\end{array}$ & $\begin{array}{l}3770 \\
4450\end{array}$ & $\begin{array}{r}\sim 2500 \\
\sim 5400 \\
\end{array}$ \\
\hline $\begin{array}{l}\text { Довжина ЗПС для } \\
\text { зльоту, м }\end{array}$ & 2500 & 1689 & 1910 & 1851 & 1969 & 1800 \\
\hline $\begin{array}{c}\text { Габарити літака, м: } \\
\text { довжина } \\
\text { висота } \\
\text { розмах крила }\end{array}$ & $\begin{array}{r}36,90 \\
9,00 \\
29,00 \\
\end{array}$ & $\begin{array}{c}29,90 \\
9,67 \\
26,00 \\
\end{array}$ & $\begin{array}{c}31,68 \\
9,73 \\
26,00 \\
\end{array}$ & $\begin{array}{c}32,30 \\
7,60 \\
23,20 \\
\end{array}$ & $\begin{array}{c}36,25 \\
7,50 \\
24,87 \\
\end{array}$ & \\
\hline Ціна, млн. дол. & & 34 & 38 & 41 & 42 & 30 \\
\hline
\end{tabular}


Унаслідок аналізу статистичних даних літаків-аналогів запропоновано концепцію забезпечення рівня досконалості, що перевершує існуючи аналоги за льотно-технічними, ресурсними, експлуатаційними та економічними характеристиками.

- аеродинамічне компонування літака має забезпечувати крейсерську аеродинамічну якість на рівні 19-20 одиниць, що на 5-7\% вище показників аналогів.

- компонування салону має забезпечувати комфрорт на рівні сучасних світових стандартів для салонів економ-класу з шагом крісел 812 мм, 3 можливістю переобладнання й випуску літаків з салонами бізнес-класу i люкс-класу.

- злітно-посадкові характеристики повинні забезпечувати безпечну експлуатацію літака що розробляється, з ґрунтових аеродромів при довжині ЗПС від 800 м, що відповідає класу D за класифікацією CHіП 2.05.08-85, СНіП 32-03-96 або класу 1В за класифрікацією ICAO, а також експлуатацію з необладнаних аеродромів;

- паливна ефективність. Має бути забезпечена шляхом зниження витрат палива на крейсерському режимі на 10-15\% в порівнянні з аналогами, до рівня 24,9 г/пас.-км;

- висока масова ефективність має бути забезпечена шляхом підвищення рівня масової досконалості конструкції та систем, відносна маса планера - не більше $27 \%$ (на 7-15\% нижче аналогів).

- силова установка повинна забезпечувати необхідний рівень тягоозброєності, при низькому рівні шуму, вібрацій і невеликі витрати палива на крейсерському режимі - не більше 0,5-0,52 кг/кгс.год. По шумам на місцевості літак повинен задовольняти вимогам глави 4 Міжнародних стандартів «Охорона навколишнього середовища», додатка 16 до Конвенції про міжнародну цивільну авіацію (том I «Авіаційний шум», 2001 р.);

- система керування й пілотажно-навігаційний комплекс мають бути виконані із застосуванням сучасного обладнання. Характеристики точності пілотажно-навігаційного комплексу повинні відповідати міжнародним вимогам (RNP, RVSM, BRNAV і PRNAV). Кабіна льотчиків виконується 3 урахуванням сучасних вимог ергономіки. Основними пристроями, на яких відображається пілотажна й навігаційна інформація, а також дані щодо основних систем літака й силових установок, $\epsilon$ кольорові рідкокристалічні дисплеї з активною матрицею;

- $\quad$ проектний ресурс планера повинен становити не менше 80000 льотних годин, термін експлуатації - не менше 30 років;

- вартість повинна становити не більше 28-30 млн. дол., що на 10-20 \% менше від середньої вартості сучасних літаків даного класу;

- експлуатаційна технологічність має забезпечувати питому трудомісткість технічного обслуговування не більше 2,5 люд.-год на 1 год польоту, а також можливість автономного поточного технічного обслуговування літака силами екіпажу;

- для забезпечення конкурентоспроможності літака мають задовольнятися вимоги сучасних норм льотної придатності (AП-25, FAR25), а також унікальні вимоги до експлуатації в умовах тропічних і гірських аеродромів; 
- для забезпечення ефективності проектування літака мають широко застосовуватися сучасні системи автоматизованого проектування (САПР) для оптимізації проектних параметрів літака, а також системи інтегрованого проектування CAD/CAM/CAE/PLM.

За результатами аналізу існуючих конкурентоспроможних літаків 3 урахуванням вимог технічного завдання та забезпечення наступності конструкції приймається рішення до схеми літака, що проектується. Наприклад, для літака що проектується, застосована нормальна аеродинамічна схема 3 високо розташованим крилом помірної стрілоподібності 3 розвиненою механізацією. Два ТРДД розташовані на пілонах під крилом. Хвостове оперення Т-подібної схеми. Фюзеляж літака $€$ самостійним модулем з вузлами кріплення опор шасі, крила, вертикального й горизонтального оперення. У фрюзеляжі розташовані герметичні кабіна екіпажу і пасажирський салон, відсік радіолокатора, відсік БРЕО та інше обладнання. Шасі - триопорне, що прибирається в польоті, 3 носовим стояком, основні опори - двостоякові (рисунок 2).

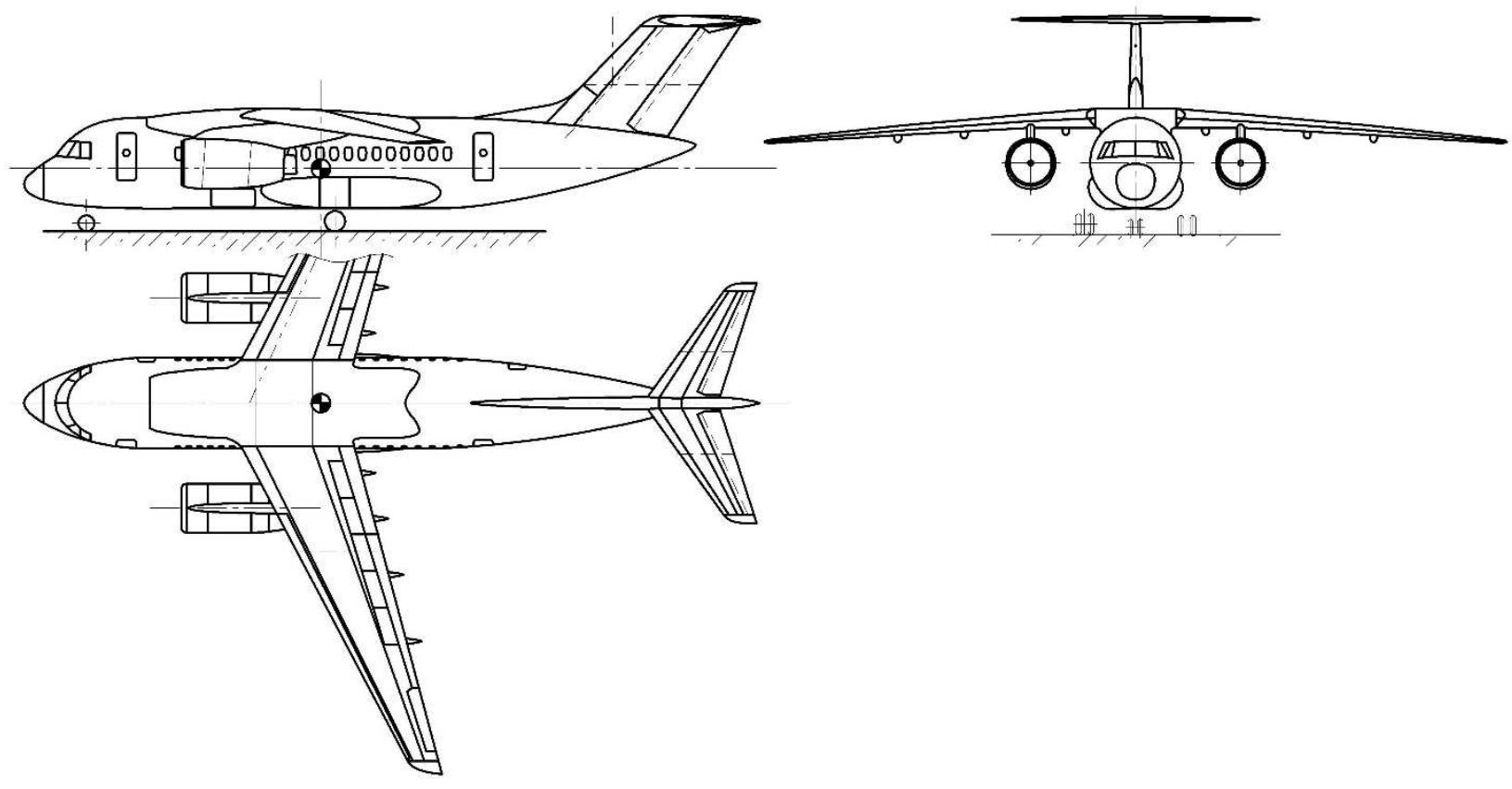

Рисунок 2 - Схема літака

Метод загального проектування регіональних пасажирських літаків реалізовано відповідно до методології інтегрованого проектування літаків $[4,10]$ у вигляді блок-схеми, показаної на рисунку 3.

Рівень досконалості регіональних пасажирських літаків визначається на основі показника собівартості пасажирських перевезень [4] і досягнення ії зниження для новостворюваного або модернізованого літака. Технічна ефективність літака або собівартість 1 тонно-кілометра перевезень (ткм) дає змогу виконати аналіз можливостей підвищення його конкурентоспроможності:

$$
a=\frac{A}{K_{\kappa .3} n_{n a c} V_{p}}, a=\frac{A}{K_{\kappa .3} m_{\kappa . h} V_{p}},
$$

де $\boldsymbol{a}$ - собівартість перевезень, грн/пас.-км або грн/ткм;

$\boldsymbol{A}$ - вартість години експлуатації літака з накладними витратами, грн/год; 
$\boldsymbol{K}_{\kappa .3}$ - коефріцієнт завантаження літака;

$\boldsymbol{n}_{\text {nac }}$ - кількість пасажирів, чол.;

$\boldsymbol{m}_{\text {к.н }}$ - маса комерційного навантаження літака, кг;

$\boldsymbol{V}_{\boldsymbol{p}}$ - рейсова швидкість польоту, км/год.

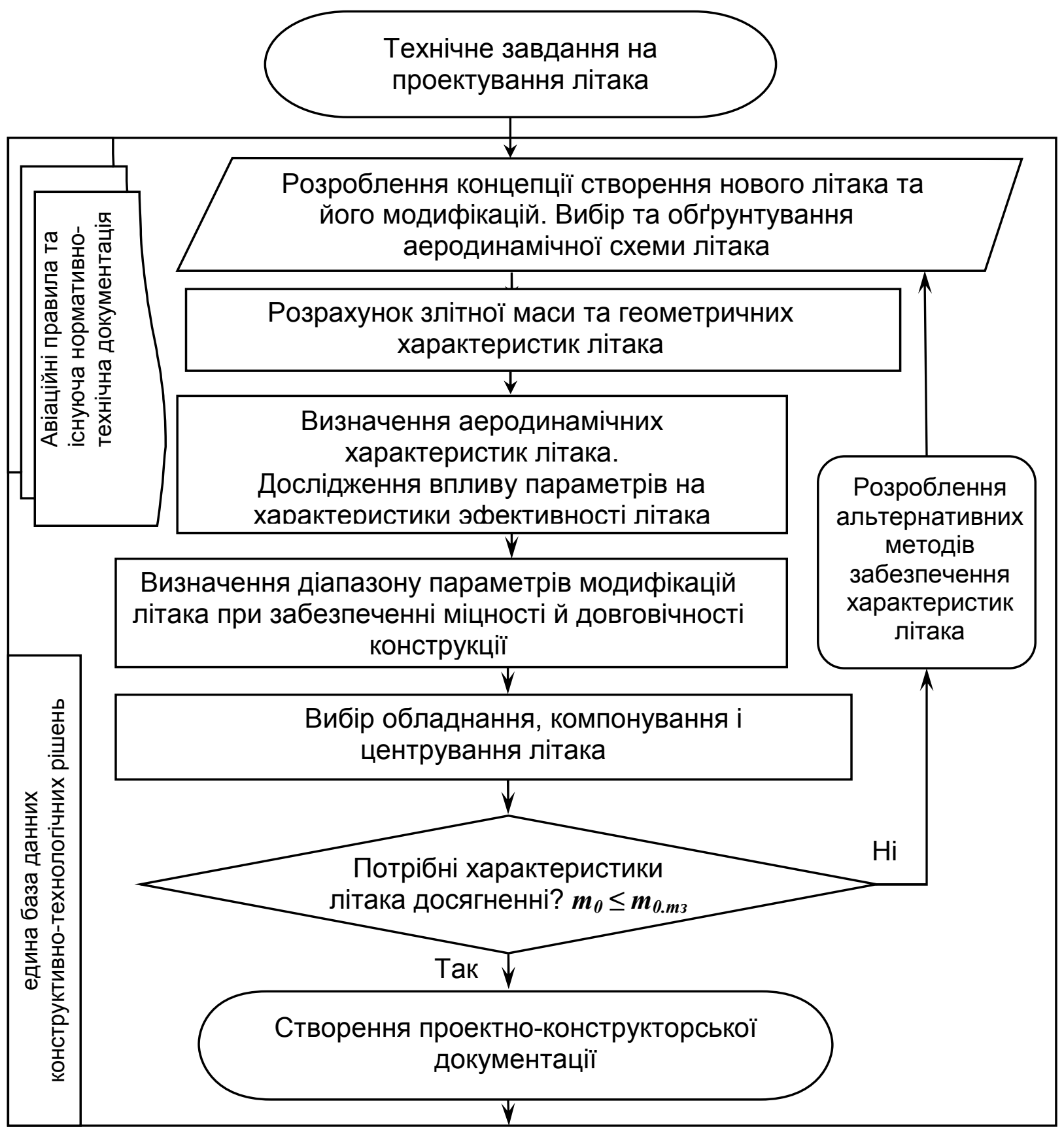

Рисунок 3 - Блок-схема методу загального проектування регіональних пасажирських літаків

Пріоритетними напрямами розвитку регіональних пасажирських літаків $є$ збільшення кількості пасажирів, маси корисного навантаження (коефіцієнта віддачі) і рейсової швидкості; зменшення витрат на експлуатацію $(\boldsymbol{A})$ літаків, які 
визначаються вартістю літака й витратами на інфраструктуру його експлуатації, систему його технічного обслуговування, вартість палива й матеріалів що витрачаються в польоті, утримання льотного, технічного та обслугового персоналу.

Коефіцієнт завантаження залежить від рівня комфорту й обслуговування, вартості квитка, дотримання розкладу польотів, реклами перевезень на літаку.

Важливим показником технічної досконалості регіонального пасажирського літака $є$ коефіцієнт паливної ефективності $[4,10]$

$$
K_{n . e}=\frac{m_{n}}{n_{n a c} L_{m}}, \quad K_{n . e}=\frac{m_{n}}{m_{\kappa . h} L_{m}}
$$

де $\boldsymbol{K}_{n . e}-$ коефріцієнт паливної ефективності, г/пас.-км, г/ткм;

$\boldsymbol{m}_{\boldsymbol{n}}$ - маса палива необхідного для виконання польоту, кг;

$\boldsymbol{m}_{\text {к.н }}$ - маса комерційного навантаження літака, кг;

$\boldsymbol{L}_{\boldsymbol{m}}$ - технічна дальність польоту, що забезпечується при повному вигорянні палива, км.

Питомі витрати на експлуатацію літака і маса палива, необхідного для виконання польоту, безпосередньо пов'язані 3 витратою двигуна, аеродинамічними характеристиками і злітною масою літака.

На етапі вибору параметрів загального вигляду пасажирського літака як критерій ефрективності доцільно використовувати злітну масу літака. Математичну залежність для визначення злітної маси літака в нульовому наближенні можна записати в такому вигляді $[5,6,9,10]:$

де $\boldsymbol{m}_{c л}-$ маса службового навантаження, кг;

$$
\boldsymbol{m}_{0}^{0}=\frac{\boldsymbol{m}_{c \Omega}+\boldsymbol{m}_{\kappa . u}}{1-\left(\overline{\boldsymbol{m}}_{\kappa o н}+\overline{\boldsymbol{m}}_{c . y}+\overline{\boldsymbol{m}}_{o \bar{\sigma}}+\overline{\boldsymbol{m}}_{\boldsymbol{n}}\right)},
$$

$\boldsymbol{m}_{\kappa . \boldsymbol{n}}$ - маса комерційного навантаження літака, кг;

$\overline{\boldsymbol{m}}_{\text {кон }}$ - відносна маса конструкції;

$\overline{\boldsymbol{m}}_{\boldsymbol{c} . \boldsymbol{y}}$ - відносна маса силової установки;

$\overline{\boldsymbol{m}}_{\text {об }}$ - відносна маса обладнання $з$ урахуванням устаткування та керування;

$\bar{m}_{n}-$ відносна маса палива.

У нульовому наближенні відносні маси конструкції, силової установки, устаткування й палива визначено на підставі статічтіческіх даних. Необхідну кількість кількість членів екіпажу 5 осіб визначено 3 урахуванням вимог авіаційних правил щодо кількості бортпровідників. Розрахункова маса одного члена екіпажу - 80 кг., Одного пасажира з багажем - 75 кг.

Вираз для визначення злітної маси літака в першому наближенні $\boldsymbol{m}_{\boldsymbol{0}}^{\boldsymbol{l}}$ набирає вигляду

$$
\boldsymbol{m}_{0}^{1}=\frac{\boldsymbol{m}_{c л}+\boldsymbol{m}_{\kappa . H}+\boldsymbol{m}_{o \sigma}}{1-\left(\overline{\boldsymbol{m}}_{\text {кон }}+\overline{\boldsymbol{m}}_{c . y}+\overline{\boldsymbol{m}}_{n}\right)} .
$$

Відносні маси конструкції, силової установки та палива в першому наближенні визначено на основі аналітичних залежностей з урахуванням поправкових коефіцієнтів. Масу обладнання, устаткування та керування $\boldsymbol{m}_{\text {об }}$ 
розраховано згідно з переліком обладнання, складеним за даними щодо літаківаналогів та з урахуванням вимог технічного завдання.

Масу службового навантаження $\boldsymbol{m}_{c л}$ для пасажирського літака визначаємо за формулою [9]

$$
\boldsymbol{m}_{c л}=\boldsymbol{m}_{э \kappa} \cdot \boldsymbol{n}_{э \kappa}+\Delta \boldsymbol{m}_{c л}
$$

де $\boldsymbol{m}_{\text {эк }}=80$ кг - маса одного члена екіпажу;

$\boldsymbol{n}_{\text {эк }}$ - кількість членів екіпажу, чол.;

$\Delta \boldsymbol{m}_{c л}-$ маса спорядження літака, кг.

Аналіз літературних джерел [5, 6, 9] і статистичних даних щодо існуючих літаків дає змогу пропонувати розраховувати масу службового навантаження, кг, для пасажирських літаків коротких та середніх авіаліній за такою фрормулою:

$$
\Delta \boldsymbol{m}_{c \boldsymbol{n}}=8,617 n_{n a c}+3,53\left(\boldsymbol{n}_{n a c} \bar{m}_{n} / K_{\text {iid }}\right)^{2 / 3},
$$

де $\boldsymbol{n}_{\text {nac }}$ - кількість пасажирів, чол.;

$\overline{\boldsymbol{m}}_{\boldsymbol{n}}$ - статистичне значення відносної маси палива;

$\boldsymbol{K}_{\text {вid }}=\boldsymbol{m}_{\text {ком }} / \boldsymbol{m}_{\boldsymbol{0}}-$ статистичне значення коефіцієнту віддачі.

Для розрахунку маси службового навантаження, кг, пасажирських літаків пропонується формула

$$
\Delta m_{c r}=14,97 n_{n a c}+4,121\left(n_{n a c} \bar{m}_{T} / K_{\text {iid }}\right)^{2 / 3},
$$

У першому наближенні відносні маси конструкції, силової установки та палива визначаємо залежно від параметрів літака на основі аналітичних залежностей з урахуванням поправових коефіцієнтів. Ці аналітичні залежності дють змогу провести параметричний аналіз впливу параметрів літака на його злітну масу 3 подальшим знаходженням значень мінімальної маси та оптимальних параметрів літака. (Більш детально алгоритм розрахунків див. [10]).

Відносну масу силової установки $\overline{\boldsymbol{m}}_{\boldsymbol{c} . \boldsymbol{y}}$ визначаємо за фрормулою

$$
\overline{\boldsymbol{m}}_{c . \boldsymbol{y}}=\boldsymbol{R} \gamma_{\partial \boldsymbol{g}} \boldsymbol{t}_{\boldsymbol{0} \max },
$$

де $\boldsymbol{R}$ - коефіцієнт, що враховує збільшення маси силової установки порівняно з масою двигунів:

$$
R=k_{1}\left(1+0,1 \frac{n_{\partial \varepsilon . p e \varepsilon}}{n_{\partial \varepsilon}}\right)\left[1+\frac{0,0236}{\gamma_{\partial \theta}}\left(1,5+0,275 y^{0,75}\right)^{2}\right] ;
$$

$\boldsymbol{k}_{\boldsymbol{l}}$ - коефріцієнт, що враховує кількість та розташування двигунів на літаку;

$\boldsymbol{n}_{\text {дв }}$ - кількість двигунів на літаку;

$\boldsymbol{n}_{\text {д. } е \text { ев }}$ - кількість двигунів, обладнаних реверсом тяги;

$\gamma_{\text {дв }}$ - питома вага двигуна, даН/даН;

$\boldsymbol{y}$ - ступінь двоконтурності двигуна.

Стартову тягоозброєність $\boldsymbol{t}_{0}$ для виконання розрахунків за наведеною формулою знаходимо як максимальну згідно з такими вимогами забезпечення крейсерського польоту із заданою швидкістю та висотою, довжини розбігу перед зльотом; продовженого зльоту при відмові одного двигуна. 
Стартову тягоозброєність, необхідну для забезпечення максимального числа $\boldsymbol{M}$ на висоті $\boldsymbol{H}$, визначаємо за формулою

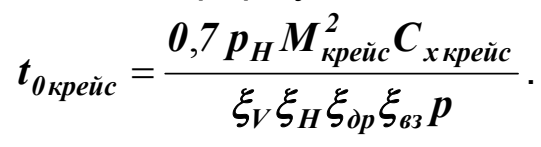

Дійсно, що на крейсерських режимах польоту

тоді

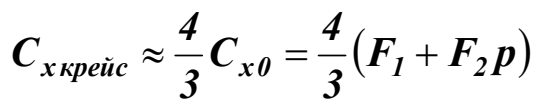

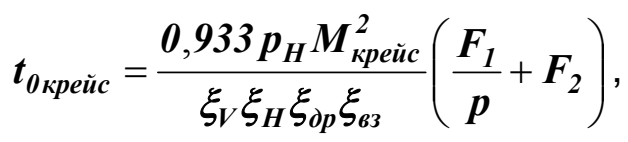

де $\boldsymbol{F}_{\boldsymbol{1}}=\boldsymbol{k}_{\text {on }} \boldsymbol{C}_{\boldsymbol{\alpha} к \boldsymbol{p}}-$ коефріцієнт лобового опору крила й оперення;

$F_{2}=\frac{C_{x \phi}}{\boldsymbol{k}_{\text {mid }}}$

$\boldsymbol{C}_{\boldsymbol{x} \boldsymbol{\phi}}$ - коефріцієнт лобового опору фюзеляжу, мотогондол, обтічників двигунів й шасі тощо;

$\boldsymbol{k}_{\text {міо }}$ - питоме навантаження на мідель, даН/м²;

$\boldsymbol{p}_{\boldsymbol{H}}$ - атмосферний тиск на висоті крейсерського польоту, даН/м²;

$\xi_{V}, \xi_{H}, \xi_{\partial p}-$ коефіцієнти, що враховують зміну тяги двигуна залежно від швидкості й висоти польоту та режиму роботи двигунів; визначається 3 паспортних даних подібних двигунів для $\boldsymbol{M}_{\kappa р е и ̆ с ~}, \boldsymbol{H}_{\text {крейс }}$;

$\xi_{\text {вз }}$ - коефріцієнт, що враховує втрату тяги, пов'язану з втратами

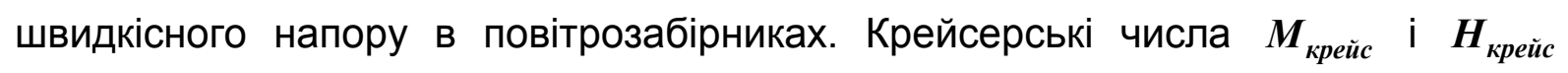
визначають за даними статистики або з досвіду експлуатації подібних літаків.

При варіації величин питомого навантаження на крило й подовження крила і при незмінних інших параметрах залежність $\boldsymbol{t}_{\text {крейс }}=f_{1}(p, \lambda$, const $)$ має вигляд, який показано на рисунку 4, криві а.

Стартову тягоозброєність, необхідну для забезпечення заданої довжини розбігу перед зльотом, визначаємо за формулою

$$
t_{0 p}=\frac{1}{\xi_{3 л}}\left[\frac{0,832 p}{L_{p} C_{y_{3 л}}}+\frac{1}{3}\left(\frac{1}{K_{3 л}}+2 f\right)\right],
$$

де $\xi_{3 л}=\xi_{V} \xi_{H} \xi_{63} \xi_{\partial p}-$ коефріцієнти, що визначають для режимів зльоту

$\boldsymbol{M}=\boldsymbol{M}_{\text {omp }}$ та $\boldsymbol{H}=\boldsymbol{0}$;

$\boldsymbol{L}_{\boldsymbol{p}}$ - довжина розбігу перед зльотом, задана в Т3, м,;

$f$ - коефіцієнт тертя коліс об поверхню ЗПС під час розбігу.

Залежність $\boldsymbol{t}_{\boldsymbol{0}}=\boldsymbol{f}_{2}\left(\boldsymbol{p}, \boldsymbol{L}_{\boldsymbol{p}}\right.$, const) показано на рисунку 4 , криві 6. 
Стартову тягоозброєність, необхідну для забезпечення продовженого зльоту при відмові одного двигуна під час розбігу перед зльотом, визначаємо за формулою

$$
\boldsymbol{t}_{0 \theta}=\frac{\boldsymbol{n}_{\partial \boldsymbol{\theta}}}{\xi_{3 .}\left(\boldsymbol{n}_{\partial \boldsymbol{\theta}}-1\right)}\left(\frac{1}{\boldsymbol{K}_{3 л}}+\operatorname{tg} \theta_{3}\right),
$$

де $\boldsymbol{n}_{\boldsymbol{}}-$ кількість двигунів, установлених на літаку;

$\operatorname{tg} \theta_{3}$ - градієнт набирання висоти на третьому етапі зльоту при відмові одного двигуна, що задається в Нормах Льотної Придатності літаків. Залежність $\boldsymbol{t}_{\boldsymbol{p}}=\boldsymbol{f}_{2}(\boldsymbol{p}, \theta, \mathrm{const})$ має вигляд, який показано на рисунку 4 , криві в.

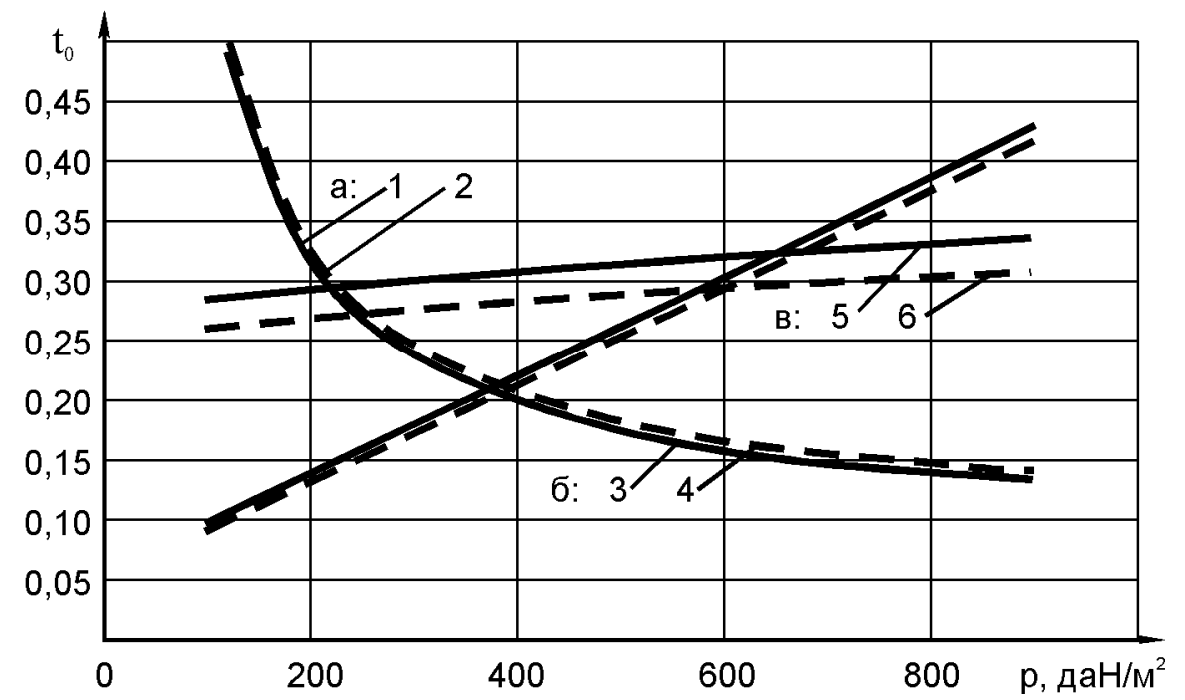

Рисунок 4 - Вплив параметрів літака на стартову тягоозброєність літака:

криві а - стартова тягоозброєність, необхідна для забезпечення максимальної швидкості $\boldsymbol{M}_{\max }$ на висоті $\boldsymbol{H}: 1-\lambda=8 ; 2-\lambda=10$;

криві 6 - стартова тягоозброєність, необхідна для забезпечення заданої довжини розбігу перед зльотом: $3-\lambda=8 ; 4-\lambda=10$;

криві В - стартова тягоозброєність, необхідна для забезпечення подовженого зльоту при відмові одного двигуна під час розбігу: $5-\lambda=8 ; 6-\lambda=10$

Відносну маса палива $\overline{\boldsymbol{m}}_{\boldsymbol{n}}$ визначаємо як суму мас:

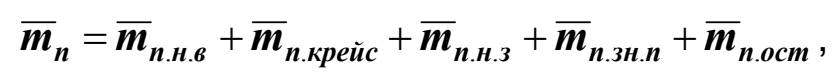

де $\overline{\boldsymbol{m}}_{\text {n.н.в }}-$ відносна маса палива, що використовується на зліт і набір висоти;

$\overline{\boldsymbol{m}}_{\text {n.крейс }}$ - відносна маса палива, що використовується при крейсерському польоті із $\boldsymbol{M}_{\text {крейс }}$ на $\boldsymbol{H}_{\text {крейс }}$;

$\overline{\boldsymbol{m}}_{\boldsymbol{n} . \boldsymbol{k} .3}$ - відносна маса навігаційного запасу палива;

$\overline{\boldsymbol{m}}_{\text {n.зн.n }}$ - відносна маса палива, що використовується на зниження та посадки;

$\overline{\boldsymbol{m}}_{\text {n.ocm }}$ - відносна маса палива, що не може бути використане;

$$
\bar{m}_{n . \text { H. }}=\frac{0,0035 H_{\text {nочч }}(1-0,03 y)}{1-0,004 H_{n o u}} \text {; }
$$




$$
\bar{m}_{n . \text { сн.n }}=0,002 H_{\text {кін }}(1-0,03 y)\left(1-0,023 H_{\text {кін }}\right) \text {, }
$$

де $\boldsymbol{H}_{\text {nоч }}, \boldsymbol{H}_{\text {кіи }}$ - значення початкової та кінцевої висоти крейсерського польоту, км;

$\boldsymbol{y}$ - ступінь двоконтурності двигуна.

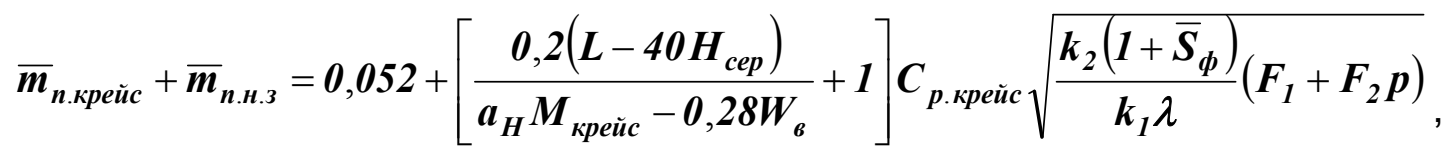

де $\boldsymbol{L}-$ дальність польоту, км;

$\boldsymbol{H}_{\boldsymbol{c} \boldsymbol{p}}=\left(\boldsymbol{H}_{\boldsymbol{\mu q u}}+\boldsymbol{H}_{\boldsymbol{к} \boldsymbol{}}\right) / \boldsymbol{2}$ - середня висота крейсерського польоту, км;

$\boldsymbol{a}_{\boldsymbol{H}}$ - швидкість звуку на середній висоті крейсерського польоту, м/с;

$\boldsymbol{M}_{\text {крейс }}$ - число Маха, що відповідає крейсерській швидкості польоту;

$\boldsymbol{W}_{\boldsymbol{s}}$ - швидкість зустрічного вітру, км/год;

$\boldsymbol{C}_{\text {p.крейс }}$ - питома витрата палива на крейсерському режимі польоту, кг/даН год.

Відносна маса конструкції складається з відносних мас крила, фрюзеляжу, оперення та шасі:

$$
\overline{\boldsymbol{m}}_{\kappa o н}=\overline{\boldsymbol{m}}_{\kappa p}+\overline{\boldsymbol{m}}_{\phi}+\overline{\boldsymbol{m}}_{\boldsymbol{}}+\overline{\boldsymbol{m}}_{\boldsymbol{u}} .
$$

Для розрахунку відносної маси крила використаємо фрормулу Бадягіна [5]

$$
\bar{m}_{\kappa p}=\frac{7,2 \boldsymbol{k}_{1} \boldsymbol{n}_{A}^{p}\left(\boldsymbol{m}_{0}^{0}\right)^{0,5} \varphi \lambda}{10^{4} \boldsymbol{p}_{\boldsymbol{0}}^{0,75} \cos { }^{1,5} \chi_{0,25}} \cdot \frac{\eta+4}{\eta+1}+\frac{4,5 \boldsymbol{k}_{2} \boldsymbol{k}_{3}}{p}+0,015,
$$

де $\quad \boldsymbol{p}-$ питоме навантаження на крило, даН// ${ }^{2}$;

$\boldsymbol{k}_{\boldsymbol{1}}$ - коефріцієнт, що враховує тип панелей;

$\boldsymbol{k}_{2}$ - коефіцієнт, що враховує наявність напливів, інтерцепторів, передкрилків і тип закрилків;

$\boldsymbol{k}_{3}$ - коефіцієнт, що враховує тип паливних баків і тип герметизації;

$\boldsymbol{n}_{\boldsymbol{A}}^{p}$ - коефіцієнт розрахункового перевантаження літака для розрахункового випадку $\mathbf{A}$;

$\varphi=\boldsymbol{b}-\boldsymbol{0 , 8 3} \overline{\boldsymbol{m}}_{\boldsymbol{T}}-$ коефіцієнт розвантаження крила паливом і двигунами;

$\lambda, \overline{\boldsymbol{c}}, \chi_{0,25}, \eta$ - значення подовження, відносної товщини профілю, стрілоподібності й звуження крила, узяті для розрахунків.

Відносну масу фюзеляжу визначаємо за формулою Шейнина [6]

$$
\overline{\boldsymbol{m}}_{\phi}=\boldsymbol{k}_{1} \lambda_{\phi} \boldsymbol{d}_{\phi}^{2}\left(\boldsymbol{m}_{0}^{0}\right)^{i}+\boldsymbol{k}_{2}+\boldsymbol{k}_{3}+\boldsymbol{k}_{4},
$$

де $\boldsymbol{k}_{1}=4,56-0,441 \boldsymbol{d}_{\boldsymbol{\phi}}$ для схем с двигунами, розташованими на фрюзеляжу;

$\boldsymbol{k}_{\boldsymbol{l}}=3,4-0,26 \boldsymbol{d}_{\boldsymbol{\phi}}$ для схем с двигунами, розташованими на крилі, або при змішаному компонуванні двигунів (DC-10, L-1011);

$\boldsymbol{i}=-\left(0,77-0,01 \boldsymbol{d}_{\boldsymbol{p}}\right)$;

$\boldsymbol{k}_{2}$ - коефріцієнт, що враховує місце кріплення основних стояків шасі;

$\boldsymbol{k}_{3}$ - коефіцієнт, який враховує місце прибирання основних стояків шасі; 
$\boldsymbol{k}_{4}$ - коефріцієнт, що враховує спосіб завантаження багажу.

Для визначення відносної маси оперення використаємо статистичну фрормулу $3[5,10]$

де

$$
\bar{m}_{o n}=0,85 k_{n} k_{o n}^{c x} p^{-0,56} \bar{S}_{o n}^{1,16}\left(m_{0}^{0}\right)^{0,16}
$$

$\boldsymbol{k}_{\boldsymbol{n}}=1$ при $\boldsymbol{p} \leq 450$ даН/ $/ \mathrm{M}^{2}$;

$\boldsymbol{k}_{\boldsymbol{n}}=0,84$ при $\boldsymbol{p}>450$ даН $/ \mathrm{M}^{2}$;

$\overline{\boldsymbol{S}}_{\text {on }}=\overline{\boldsymbol{S}}_{2 . \mathrm{o}}+\overline{\boldsymbol{S}}_{\boldsymbol{B} . \mathrm{o}}$;

$\boldsymbol{k}_{\text {on }}^{c x}=\frac{1,564-0,0011 S_{\text {on }}}{3,1+0,0038 p}$ для низько розташованого горизонтального оперення;

$$
\begin{aligned}
\boldsymbol{k}_{o n}^{c x} & =\frac{1,33-0,0032 S_{o n}}{1,295+0,0028 p} \quad \text { для Т-подібного оперення; } \\
S_{o n} & =\bar{S}_{o n} \cdot\left(\boldsymbol{m}_{0}^{0} / p\right)
\end{aligned}
$$

Для розрахунку відносної маси шасі використаємо формулу Фадеєва [5]

$$
\bar{m}_{u}=k_{u} k_{d \phi} \frac{m_{0}^{0}+204000}{m_{0}^{0}+29000}
$$

де $\quad \boldsymbol{k}_{\boldsymbol{u}}-$ коефріцієнт, що враховує кількість основних стояків шасі;

$\boldsymbol{k}_{d \phi}-$ коефріцієнт, що враховує вплив на масу шасі розмірів фрюзеляжу і типу двигунів.

Метод, який запропоновано для загального проектування регіональних пасажирських літаків апробовано 3 використанням параметрів літаків ДП «Антонов» ряду Ан-148.

Для визначення діапазону параметрів можливих модифікацій розрахунок маси виконано для різних значень проектних параметрів. На рисунку 5 зображено залежність маси від питомого навантаження на крило при різних значеннях подовження крила й дальності польоту для компонування на 75 пасажирів.

Унаслідок розрахунку отримано залежність маси літака від питомого навантаження на крило та його подовження, визначено мінімальне значення маси (37000 кг), що отримано при навантаженні на крило в діапазоні $500 \ldots 550$ даН// ${ }^{2}$. У розрахунку враховано обмеження питомого навантаження на крило за посадковою швидкістю і нормальним перевантаженням при польоті в турбулентній атмосфері.

Рекомендована величина питомого навантаження на крило становить 525 даН// ${ }^{2}$, а подовження - 9, що забезпечує мінімальну величину злітної маси літака 37000 кг при дальності 2100 км і 39000 кг при дальності 4240 км.

Аналогічним чином мінімальну масу визначено для модифікацій 3 компонуванням салону на 82 пасажири при дальності польоту від 2100 4240 км. Отримані результати показано на рисунку 6. Діапазон зміни злітної маси - від 35000 до 41500 кг. 


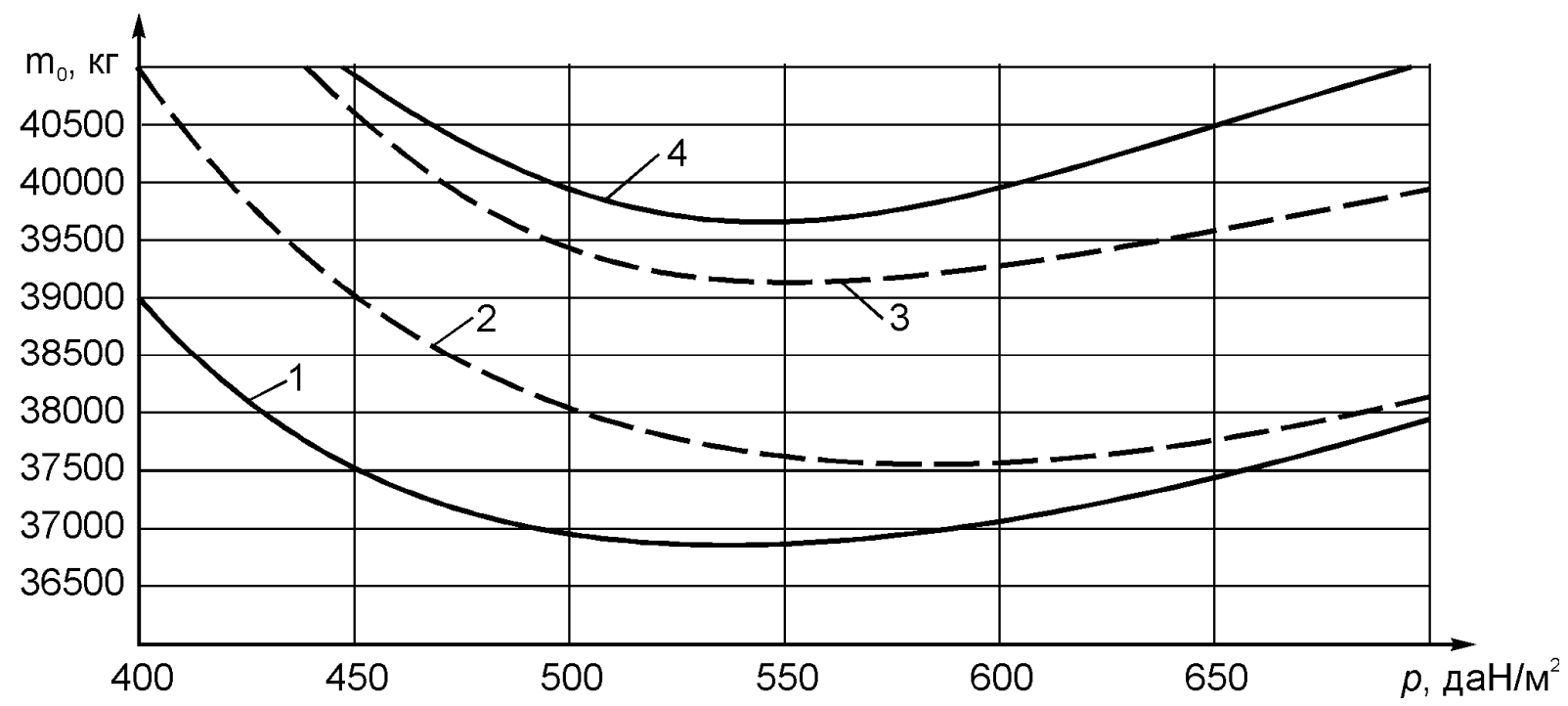

Рисунок 5 - Вплив подовження крила та питомого навантаження на злітну масу літака:

$1-\lambda=8, \boldsymbol{L}=2100 \mathrm{kм} ; 2-\lambda=10, \boldsymbol{L}=2100 \mathrm{\kappa м} ; 3-\lambda=10, \boldsymbol{L}=4240 \mathrm{\kappa м}$;

$4-\lambda=8, L=4240 \mathrm{Kм}$

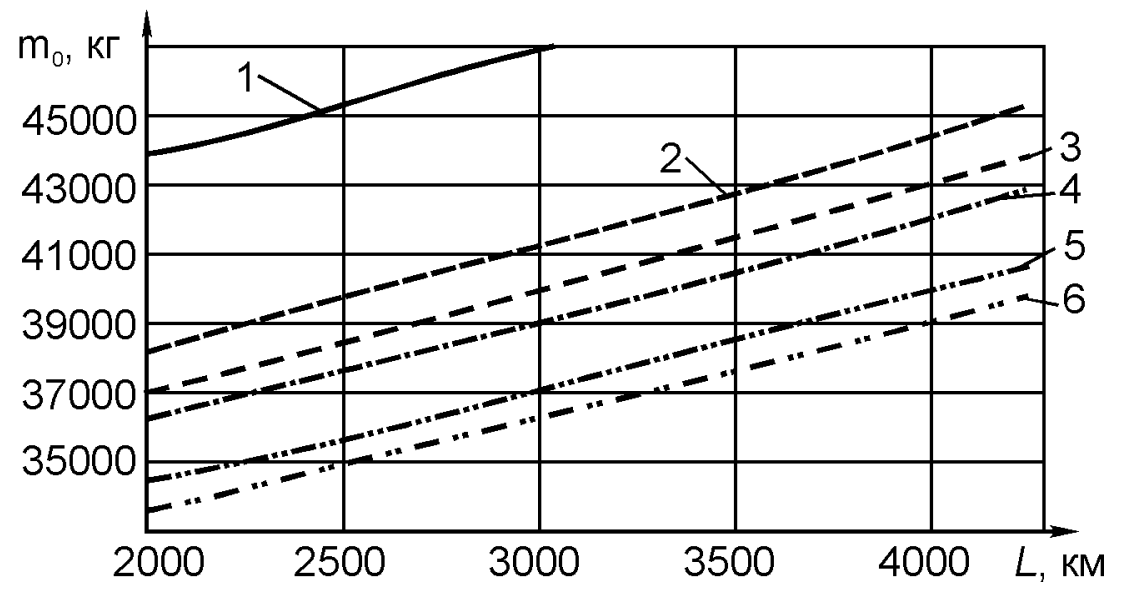

Рисунок 6 - Вплив дальності польоту і кількості пасажирів на злітну масу літака:

кількість пасажирів, чол. 1 - 99; 2 - 85; 3 - 82; 4 - 80; 5 - 75; 6 - 73

Заданий рівень масової досконалості конструкції передбачається забезпечити шляхом широкого застосування композиційних матеріалів (КМ). Вертикальне й горизонтальне оперення має бути повністю виконане з КМ, як і носок, закінцівки й уся механізація крила (передкрилок, закрилки, елерони, тримери і сервокомпенсатори). Фюзеляж, кесон крила і центроплана передбачається виготовляти з алюмінієвих сплавів, щоб зберегти технологічну наступність і спростити підготовку до виробництва машини на вітчизняних авіапідприємствах. Завдяки значному застосуванню КМ і розширеному використанню методів інтегрованого проектування 3 урахуванням втоми розрахункова відносна маса конструкції виходить на 15-20\% меньшою, ніж існуючих аналогів, при заданому проектному ресурсі планера в 80000 год. Це 
має забезпечити проектний термін експлуатації літака 30 років при річному нальоті 2800...3500 год.

За результатами аналізу ТTХ двигуна й аеродинамічних характеристик літака зроблено висновок, що для забезпечення заданого рівня паливної ефективності $(0,0245$ кг/пас.-км) на крейсерському режимі польоту необхідно забезпечити крейсерську аеродинамічну якість літака не нижче 18-19. 3 огляду на вимоги Т3 з експлуатації літака на грунтових і необладнаних аеродромах прийнято рішення про розташування крила за схемою «високоплан» i розміщення двигунів над крилом. За попередніми розрахунками для забезпечення заданої дистанції зльоту необхідним $\epsilon$ досягнення злітнопосадкової якості 10-12 при $\mathrm{C}_{\mathrm{y}}=2,4$. На основі попередніх розрахунків та оптимізації геометричних параметрів крила з використанням САПР прийнято рішення про застосування стрілоподібного крила великого подовження 3 автоматичним багатосекційним передкрилком і багатощілинним двосекційним закрилком з навантаженням на крило до 550 даН/м². Оптимізація проводилася за аеродинамічною якістю на крейсерському режимі за умови забезпечення заданих злітно-посадкових характеристик 3 урахуванням застосування механізації. Варійованими параметрами були відносна товщина профрілю крила, питоме навантаження на крило, подовження крила і тип закінцівки. Отримано розрахункову величину аеродинамічної якості для крейсерського режиму - 19,4. Подальші роботи щодо поліпшення аеродинамічної досконалості літака будуть проводитися при більш ретельному опрацюванні аеродинамічного компонування шляхом підбору оптимальної аеродинамічної і геометричної скрученості крила, а також у процесі уточнення взаємного впливу різних агрегатів конструкції літака.

На підставі отриманих значень питомого навантаження на крило і злітної маси визначені геометричні параметри літака.

Площа крила $\boldsymbol{S}=\frac{\boldsymbol{m}_{\boldsymbol{0} \min } \boldsymbol{g}}{\boldsymbol{1 0} \cdot \boldsymbol{p}_{\text {onm }}}=87,3 \mathrm{~m}^{2}$. Розмах крила: $\boldsymbol{l}=\sqrt{\lambda_{\text {onm }} \boldsymbol{S}}=28,9$ м. Коренева хорда крила $\boldsymbol{b}_{0}=\frac{2 S}{l} \frac{\eta}{\eta+1}=4,83$ м (для даного типу літаків $\left.\eta=4\right)$. Кінцева хорда крила $\boldsymbol{b}_{\boldsymbol{k}}=\frac{\boldsymbol{b}_{\boldsymbol{0}}}{\eta}=1,2$ м. Координата носка кінцевої хорди крила відносно носка кореневої хорди $\boldsymbol{x}_{\boldsymbol{\mu} \boldsymbol{x}}=\frac{\boldsymbol{l}}{2} \boldsymbol{t g} \chi_{n . \kappa}=13,5 \mathrm{M}$, де $\chi_{n . \kappa} \approx 25^{\circ}-$ стрілоподібність крила по передній кромці. Середня аеродинамічна хорда крила $\boldsymbol{b}_{\boldsymbol{a}}=\frac{2 \cdot\left(1+\eta+\eta^{2}\right) \boldsymbol{b}_{0}}{3 \eta(1+\eta)}=3,4$ м. Площа горизонтального оперення $\boldsymbol{S}_{2 . o}=\overline{\boldsymbol{S}}_{2 . \boldsymbol{o}} \boldsymbol{S}=17,95$ $\mathrm{M}^{2}$, де $\bar{S}_{z . o .} \approx 0,21$. Розмах горизонтального оперення $\boldsymbol{l}_{\text {z.o }}=\sqrt{\lambda_{2 . o} \boldsymbol{S}_{\text {z.o }}}=9,346 \mathrm{M}$, де $\lambda_{\text {z.o }} \approx 5$. Площа вертикального оперення $\boldsymbol{S}_{\boldsymbol{c} . \boldsymbol{o}}=\overline{\boldsymbol{S}}_{\boldsymbol{b . o}} \boldsymbol{S}=19,91 \mathrm{M}^{2}$, де $\overline{\boldsymbol{S}}_{\boldsymbol{\theta} . \boldsymbol{o}} \approx 0,2$. Довжина фюзеляжу $l_{\phi}=\lambda_{\phi} d_{\phi}=26,2 \mathrm{M}$, де $\lambda_{\phi} \approx 7,8, \boldsymbol{d}_{\phi} \approx 3,35 \mathrm{~m}$.

Розташування крила й оперення по довжині фююеляжу визначається плечима горизонтального й вертикального оперень, які в першому наближенні вибирають виходячи з величини коефіцієнта статичного моменту площі горизонтального оперення: 


$$
\boldsymbol{L}_{2 . o}=\frac{\boldsymbol{A}_{2 . o} \boldsymbol{b}_{a}}{\overline{\boldsymbol{S}}_{2 . o}}=20,3 \mathrm{M} .
$$

Для літаків цього класу $\boldsymbol{A}_{2 . o} \approx 1$.

Для літака з високим розташуванням крила висота шасі визначається мінімальною відстанню від нижньої точки фюзеляжу до поверхні злітнопосадкової смуги. При цьому висота $\boldsymbol{H}$ має забезпечити кут перекидання $\varphi \approx 10^{\circ}$ і кут винесення головних стояків шасі $\gamma=\varphi+3^{\circ}$.

Отримані геометричні й масові характеристики літака збігаються 3 характеристиками літаків ДП «Антонов» ряду Ан-148.

Згідно 3 отриманими геометричними параметрами розроблено креслення загального вигляду літака (рисунок 7).

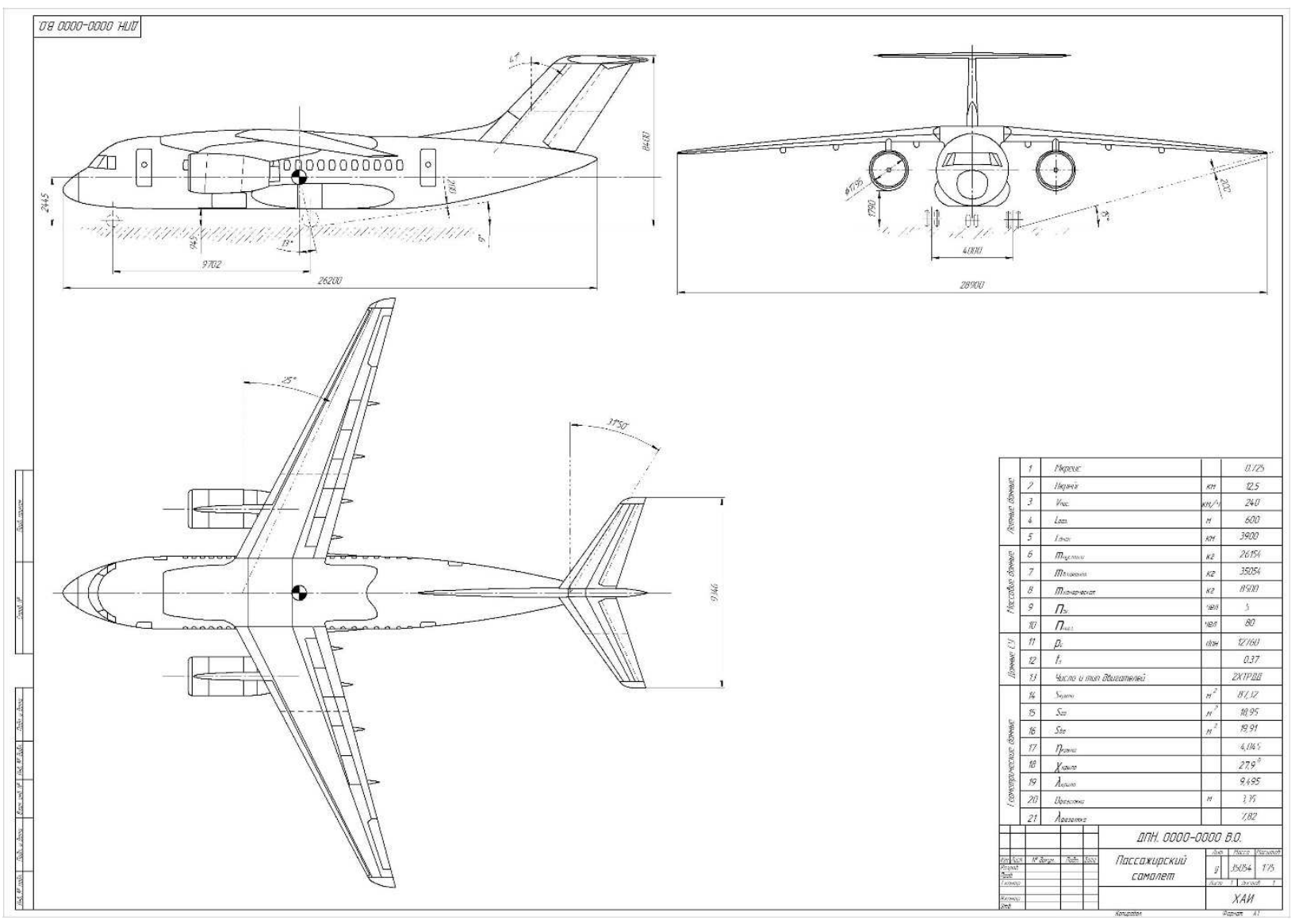

Рисунок 7 - Загальний вигляд літака

Параметричне моделювання літака виконано за допомогою системи Siemens NX. Було створено моделі окремих вузлів та агрегатів літака, після чого проведено їх взаємну ув'язку. Унаслідок цього отримано параметричну майстергеометрію проектованого літака (рисунок 8), з якою асоціативно пов'язані всі конструктивні елементи, що знаходяться всередині літака, унаслідок чого створюється модель розподілу простору літака. 


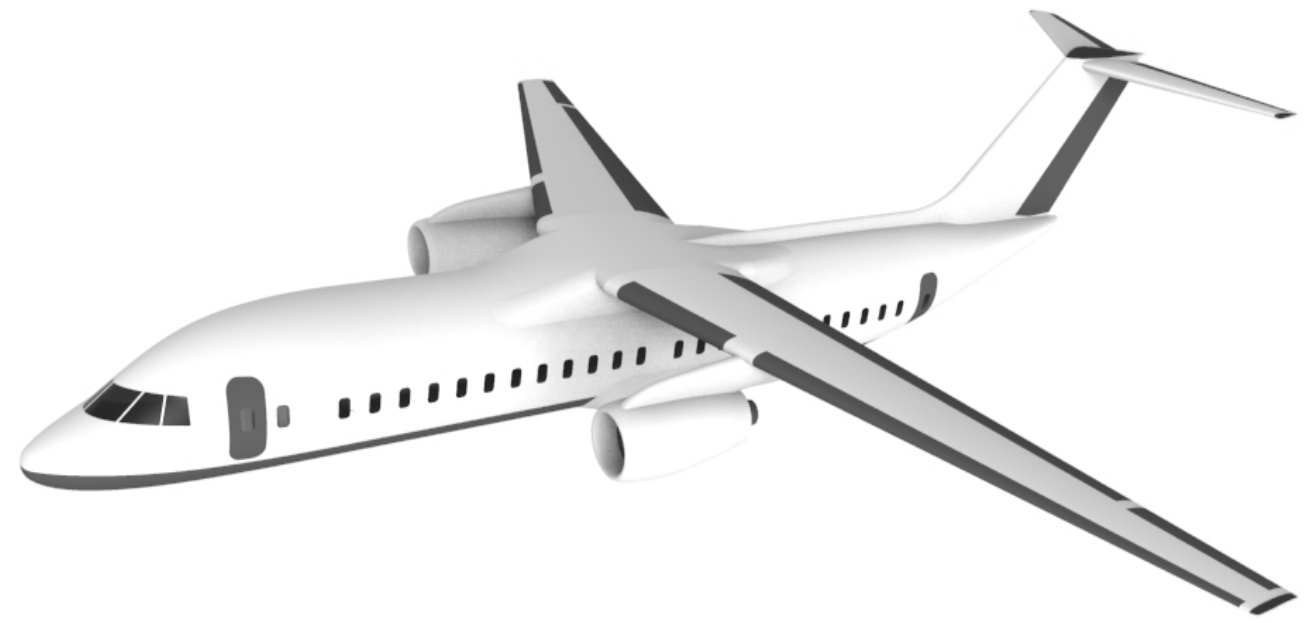

Рисунок 8 - Параметрична модель майстер-геометрії літака

Оскільки цей літак, як і літаки ДП «Антонов» ряду Ан-148 та Ан-74, виконано за схемою «високоплан», при якій двигуни розташовуються значно вище над поверхнею ЗПС, ніж двигуни аналогів (наприклад, виконаних за схемою «низькоплан»: ERJ 170/175). Завдяки цьому двигуни значно краще захищені від потрапляння в них сторонніх предметів, бруду й пилу з поверхні ЗПС (рисунок 9). Таким чином, імовірність дострокового зняття двигуна для ремонту $\epsilon$ на порядок нижчою, ніж у ERJ 170/175. Тому, на відміну від конкурентів, літак може експлуатуватися на ґрунтових і засмічених ЗПС і $\epsilon$ єдиним із ближньомагістральних літаків-аналогів, який сертифіковане на зліт і посадку з ґрунтових смуг.
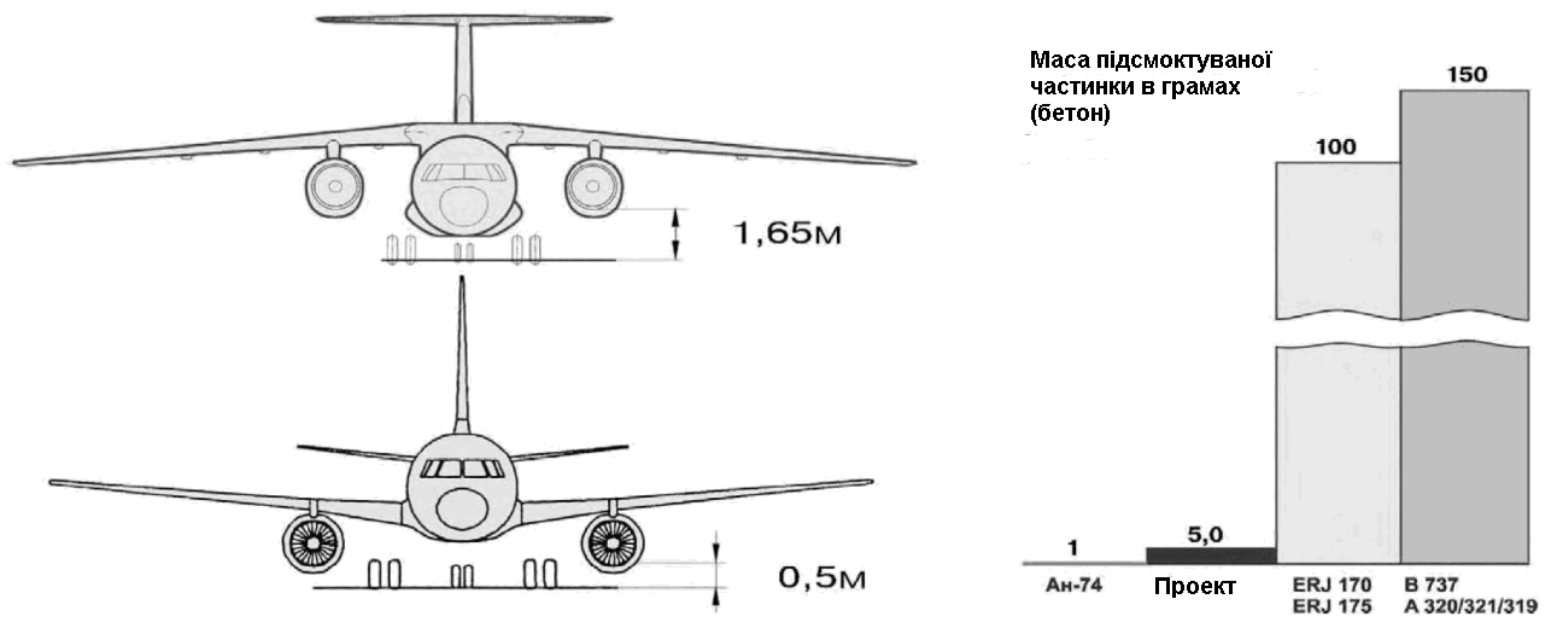

Рисунок 9 - Переваги схеми «високоплан»

Таким чином, схема літака «високоплан», при якій двигун віддалений від ЗПС на 1,65 м, забезпечує безпечну експлуатацію літака на широкій мережі слабо підготовлених аеродромів країн СНД, а також у будь-яких інших регіонах світу.

Окрім того, схема «високоплан» дала можливість зменшити висоту розташування підлоги пасажирської кабіни над землею, й застосувати вхідні двері-трап, які завжди $є$ на літаку, і у відкритому положенні перетворюються на зручні сходи для пасажирів. Це технічне рішення суттєво підвищило 
автономність застосування літака, прискорило і здешевило його експлуатацію (адже в аеропортах подавання трапу до літака $є$ окремою платною послугою).

При розробленні компонування салону забезпечено комфорт на рівні сучасних світових стандартів для салонів економ-класу 3 максимально можливим наближенням за комфортом до бізнес-класу, і можливістю переобладнання і випуску літаків 3 салонами бізнес-класу і люкс-класу. Стандартне компонування пасажирської кабіни розраховане на 75 пасажирів 3 розміщенням пасажирських крісел за схемою «3+2». Крісла розміщуються 3 кроком 790 мм, ширина крісла 418 мм, ширина підлокітників 53 мм, мінімальна ширина проходу 384 мм, максимальна - 508 мм, середня висота проходу 1820 мм.

Компонування крісел літака виконана аналогічно до літаків ДП «Антонов» ряду АН-148 за схемою «3+2» в ряду (у конкурентів - «2+2» у ряді), що дало змогу зменшити подовження його пасажирської кабіни. 3 огляду на комфорт пасажирів схема розташування крісел «3+2» $€$ кращою, ніж схема розташування крісел «2+2», що застасовується на регіональних літаках Embraer і Bombardier. Через більшу ширину та меншу довжину салону пасажирська кабіна Ан-148-100 має більш об'ємний вигляд, що наближає ії до кабін середньо-магістральних літаків. Більше подовження пасажирських кабін конкурентів ERJ 170/175 і CRJ 700/705 створює ефект «труби» або «тунелю», що негативно відбивається на підсвідомій оцінці і відчутті пасажирами комфорту кабіни в цілому. Для літаків ряду CRJ 700/705 цей ефект має особливо виражений характер унаслідок сильного обтиснення поперечного перерізу фюзеляжу, меншої висоти салону по проходу (1890 мм проти 2000 мм) і ширини проходу (406 мм проти 480 мм). Менша, ніж у конкурентів, довжина пасажирської кабіни дає змогу вирішити проблему аварійної евакуації пасажирів тільки з допомогою передніх і задніх дверей та люків - без організації посередині фююеляжу спеціальних аварійних люків. Це зменшило масу та спростило конструкцію літака. Вхідна двер $1800 \times 1070$ мм розташована по лівому борту спереду салону, по правому борту - службова дверь 1651×533 мм, що в аварійній ситуації використовується як аварійний вихід типу II.

Схему компонування салону показано на рисунку 10.

Окрім того, більша ширина пасажирського салону дає змогу організувати найбільш об'ємні в цьому класі літаків багажні полиці. Поперечні розміри полиць становлять $250 \times 665$ мм / $250 \times 560$ мм, у той час як у літаків CRJ 700/705 $200 \times 380$ мм, а у літаків ERJ 170/175 - $250 \times 400$ мм.

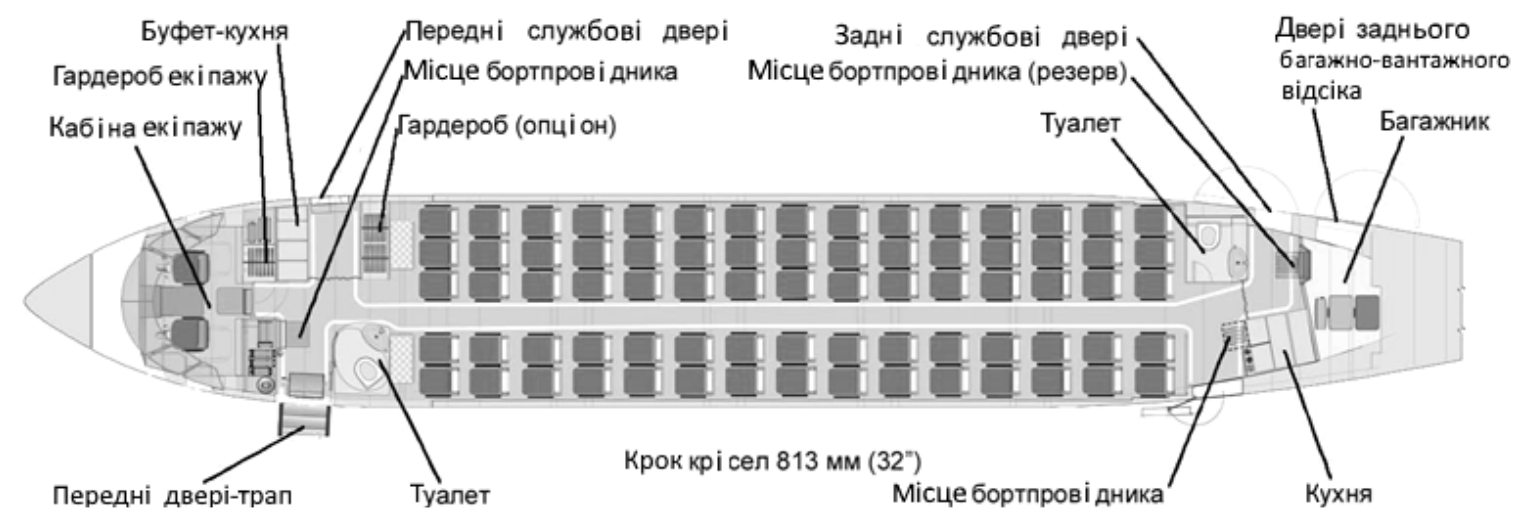

Рисунок 10 - Схема компонування салону літака на 75 пасажирів 
Порівняння поперечних перерізів фрюзеляжів літака Ан-148-100 та його аналогів зображено на рисунку 11.

Рівень фрактичного нальоту літака - 300 льотних годин за місяць (3600 льотних годин за рік) на 44\% перевищує середній світовий рівень нальоту регіональних літаків, що становить 3000 льотних годин за рік. Високий рівень нальоту літака забезпечує зниження прямих експлуатаційних витрат (ПЕВ) на 1 крісло-кілометр разом зі збільшенням операційного доходу від перевезення пасажирів.

Кабіну пілотів (рисунок 12) виконано з урахуванням сучасних вимог ергономіки з розміщення екіпажу. Бортове обладнання являє собою пілотажнонавігаційний комплекс на цифровій основі 3 інформаційно-аналітичним забезпеченням упровадження геоінформаційних і GPS/ГЛОНАCС-технологій.

Комплекс бортового електронного устаткування літака складається 3: системи ближньої і дальньої навігації, бортової авіоніки, що інтегрує в комплекс основні літакові системи, систем радіозв'язку, радіолокації для виявлення грозових фронтів, турбулентності атмосфери і здійснення оглядових функцій, системи розважання пасажирів.

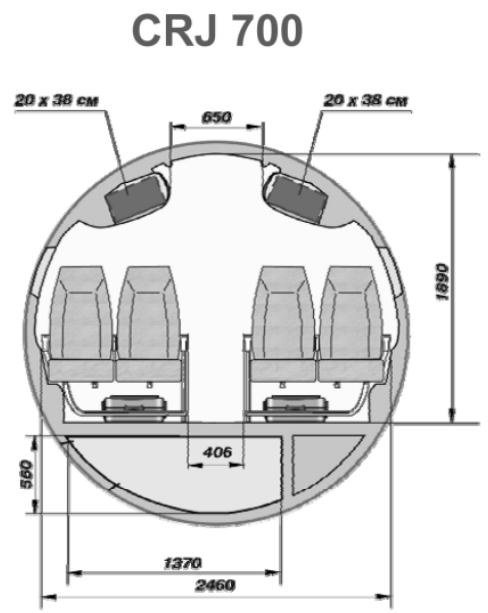

Ан-148

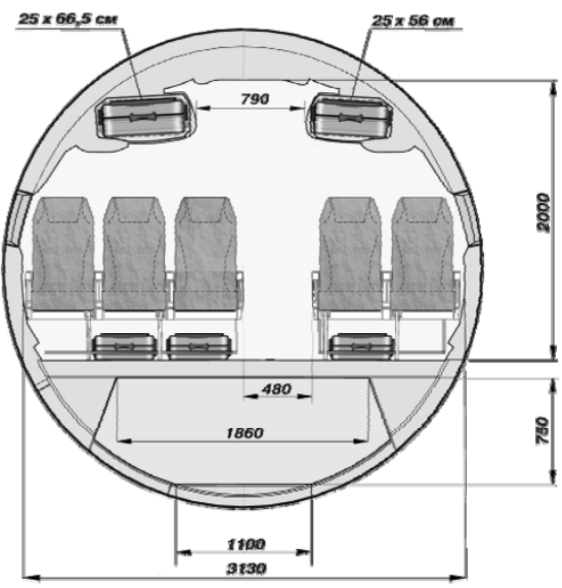

ERJ 170/175

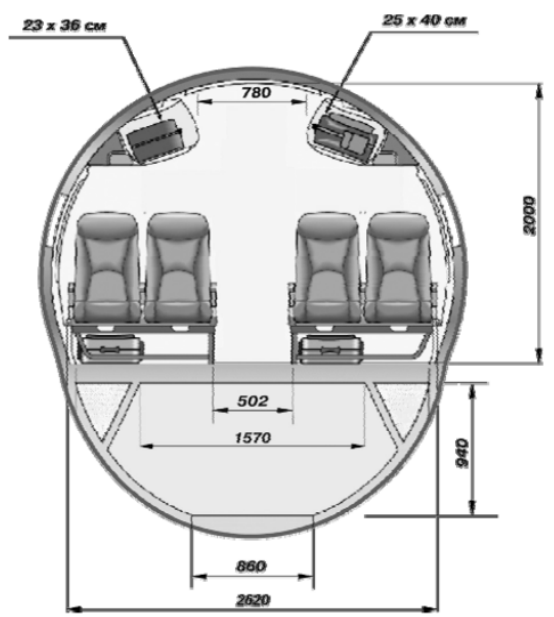

\section{Размеры багажных полок}

Ан-148

CRJ 700

ERJ 170/175
$25 \times 66,5(56) \mathrm{cm}$

$20 \times 38 \mathrm{~cm}$

$25 \times 40 \mathrm{~cm}$

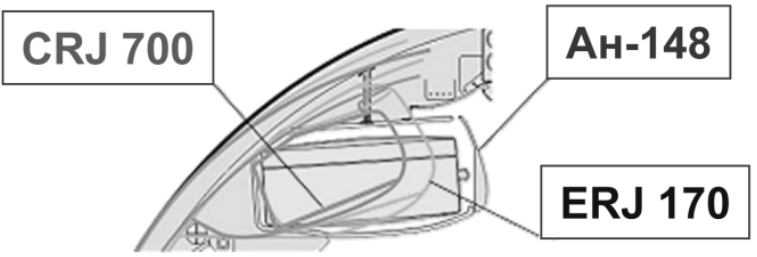

Рисунок 11 - Порівняння поперечних перерізів фрюзеляжів літака Ан-148-100 та його аналогів.

Характеристики точності пілотажно-навігаційного комплексу відповідають міжнародним вимогам (RNP, RVSM, BRNAV i PRNAV).

До складу бортового обладнання входить устаткування, що забезпечує такі умови експлуатації:

- виконання польоту візуально і за приладами;

- забезпечення польоту вдень і вночі, у простих і складних метеоумовах, у будь-яку пору року; 
- забезпечення польотів у районі аеродрому, по трасах всередині держави і по міжнародних повітряних трасах і лініях на 5-хвилинному інтервалі і з вертикальним ешелонування 300 м, над безорієнтирною i малопересіченою земною поверхнею і над акваторією при польоті по треках.

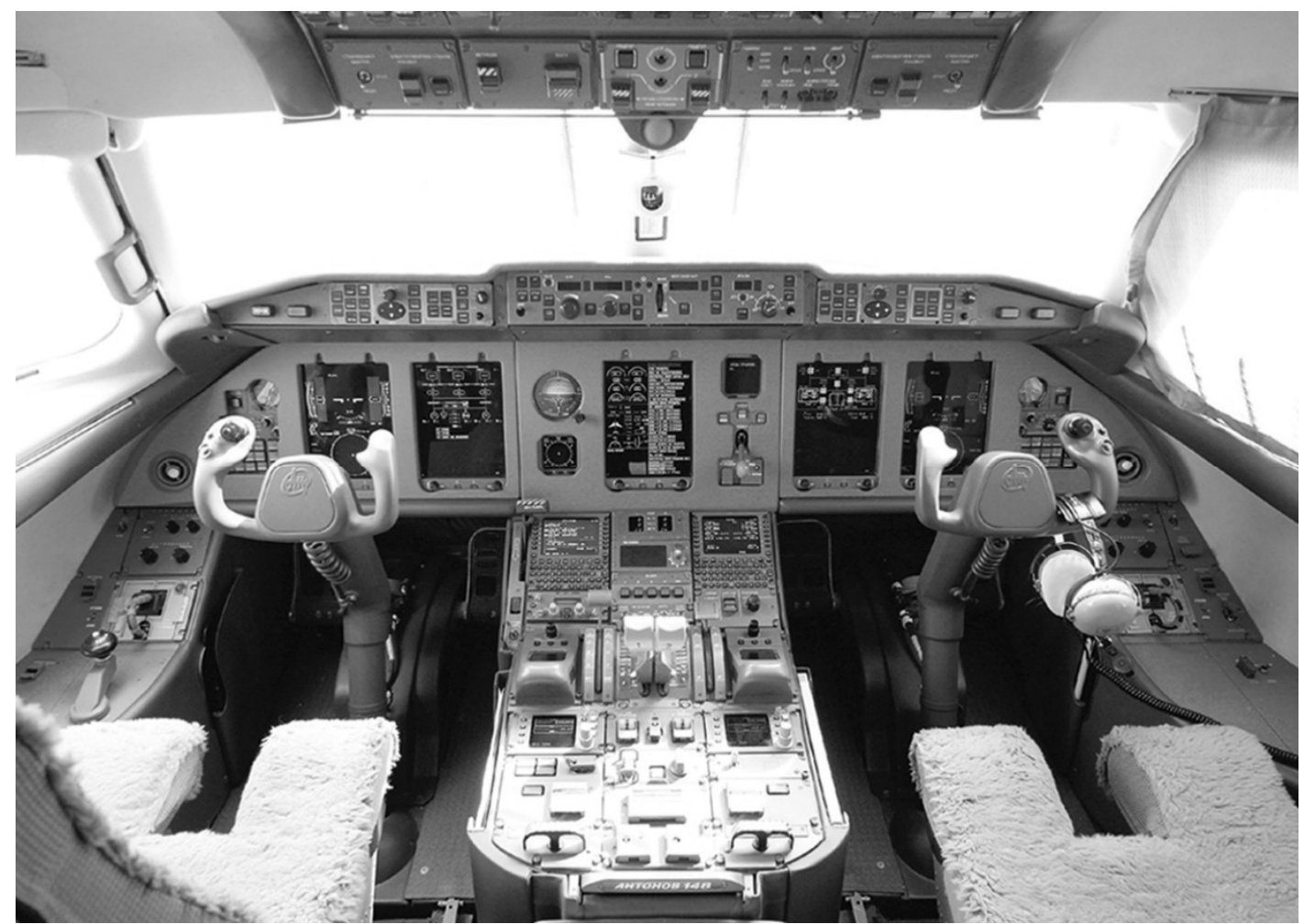

Рисунок 12 - Кабіна пілотів літака

Посадка літака повинна бути забезпечена за IIIA категорією IKAO, висота прийняття рішення - 30 м.

За фрізико-географічними умовами політ має виконуватися над рівнинною, горбистою і гірською місцевістю в діапазоні геодезичних широт від $70^{\circ}$ північної до $55^{\circ}$ південної, $180^{\circ}$ за довготою.

Бортове обладнання повинно складатися з таких основних елементів:

- LCR-93 - система визначення курсу й положення літака (курс-вертикаль);

- КІ-13 - суміщений компас;

- АГБ-96 - авіагоризонт;

- ІК ВСП - інформаційний комплекс висотно-швидкісних параметрів;

- РСБН-85 - радіотехнічна система ближньої навігації;

- DME/p-85 - літаковий далекомір (2 комплекти);

- КУРC 93М;

- ВСС-100 - обчислювальна система літаководіння;

- САУ - система автоматичного керування;

- БВУ - блок обчислювального пристрою САУ;

- ТСАС-2000 - система запобігання зіткненню в повітрі;

- АРК-25 - автоматичний радіокомпас;

- СО-96 - літаковий відповідач дальності;

- Р-855А - радіостанція зв'язку. 
Основними пристроями, на яких відображається пілотажна й навігаційна інформація, а також дані щодо основних систем літака й силових установок, $\epsilon$ кольорові рідкокристалічні дисплеї з активною матрицею (AMLCD) - основний польотний дисплей (індикатор) (PFD) і багатофункціональний дисплей (MFD). У разі відмови будь-якого індикатора можливим $€$ перерозподіл інформації, яка відображається, між рештою індикаторів.

Комплекс забезпечено багатофункціональними пультами керування для ефективної взаємодії пілотів і повітряного судна з метою забезпечення всіх режимів польоту і безперебійного контролю апаратури в польоті.

Доцільно розглянути питання центрування літака.

Розрахунок центрування літака проведено в певній послідовності.

Положення центрів маси всіх частин літака, агрегатів і вантажів визначаються за кресленням компонування. При заповненні центрувальних відомостей (табл. 2) ураховано маси й положення всіх агрегатів, обладнання, комерційного та службового навантаження.

Центрувальні відомості складено для таких випадків:

1) порожній літак, $\boldsymbol{m}_{\text {nop }}=21$ т.;

2) зліт, шасі випущено, максимальне комерційне навантаження, $\boldsymbol{m}_{0}=40 \mathrm{~T}$;

3) набір висоти, шасі прибрано, політ на максимальну дальність, $\boldsymbol{m}_{0}=40 \mathrm{~T}$;

4) посадка, шасі випущено, пасажири в передній частині салону, $\boldsymbol{m}_{0}=33$ т;

5) зниження, шасі прибрано, пасажири в хвостовій частині салону, $\boldsymbol{m}_{0}=33$ т;

Координати центра маси літака визначають як $\boldsymbol{x}_{\boldsymbol{u} . м}=\frac{\sum \boldsymbol{m}_{\boldsymbol{i}} \cdot \boldsymbol{x}_{\boldsymbol{i}}}{\sum \boldsymbol{m}_{\boldsymbol{i}}}$.

Центрування літака розраховують за фрормулою $\boldsymbol{x}=\frac{\boldsymbol{x}_{u . m}-\boldsymbol{x}_{\boldsymbol{a}}^{\prime}}{\boldsymbol{b}_{\boldsymbol{a}}}$, де $\boldsymbol{x}_{\boldsymbol{a}}^{\prime}=$ = 10585 мм - координата носка САХ відносно носка фрюзеляжу; $\boldsymbol{b}_{\boldsymbol{a}}=3401$ мм середня аеродинамічна хорда. Вертикальне положення центра маси $\boldsymbol{y}_{\text {и.м }}$ визначають так само.

Складаємо центрувальні відомості для всіх агрегатів. У таблиці 2 наведено значення мас і координати для злітної конфігурації. В інших конфігураціях положення центра мас шасі і маса палива змінюються відповідно до випадку компонування. Розглянемо найбільш характерні випадки завантаження літака. Результати розрахунків наведено в таблиці 3.

Результати розрахунків центрування показано на рисунку 13 у вигляді діаграми експлуатаційного центрування.

Базуючись на отриманих даних, зробимо попередній висновок про статичну стійкість та керованість літака. Умова стійкості літака має вигляд

$$
\overline{\boldsymbol{x}}_{\boldsymbol{F}}-\overline{\boldsymbol{x}}_{\text {u...2.2.3}}=0,04-0,06,
$$

де $\overline{\boldsymbol{x}}_{\text {и.м.2.3 }}$ - гранично задня центрівка.

Для літака, що проектується, параметри стійкості становлять

- положення фокусу - 0,4625;

- граничне заднє центрування - 0,41. 
Таблиця 2 - Центрувальна відомість

\begin{tabular}{|c|c|c|c|c|c|}
\hline Найменування & $\boldsymbol{m}_{i}, \mathrm{~K} \Gamma$ & $x_{i}, \mathrm{M}$ & $m_{i} \cdot x_{i}, \mathrm{~K} \Gamma \cdot \mathrm{M}$ & $y_{i}, \mathrm{M}$ & $\boldsymbol{m}_{i} y_{i}, \mathrm{~K} \Gamma \cdot \mathrm{M}$ \\
\hline \multicolumn{6}{|c|}{ Конструкція планера } \\
\hline Крило & 3942 & 11,986 & 47248,81 & 4,031 & 15890 \\
\hline Фюзеляж & 4106,25 & 12,5 & 51328,13 & 2,333 & 9580 \\
\hline$\Gamma \mathrm{O}$ & 592,32 & 14,683 & 8697,035 & 8,079 & 4785 \\
\hline $\mathrm{BO}$ & 623,13 & 11,817 & 7363,527 & 5,618 & 3501 \\
\hline Оперення & 1215,45 & & 16060,56 & & 8286 \\
\hline Шасі & 1543,95 & & 15744,28 & & 446 \\
\hline Носовий стояк & 308,79 & 2,435 & 751,9037 & 0,395 & 122 \\
\hline Основні стояки & 1235,16 & 12,138 & 14992,37 & 0,262 & 324 \\
\hline Силова установка & 3849,14 & 8,062 & 31031,77 & 2,533 & 9750 \\
\hline BCY & 80 & 25,897 & 2071,76 & 3,12 & 250 \\
\hline Планер & 14736,79 & & 163485,3 & & 34202 \\
\hline \multicolumn{6}{|c|}{ Обладнання } \\
\hline $\begin{array}{c}\text { Радіолокаційне } \\
\text { обладнання }\end{array}$ & 500 & 1,4 & 700 & 1,862 & 931 \\
\hline Радіообладнання & 300,44 & 3,78 & 1135,663 & 1,872 & 562 \\
\hline Електрообладнання & 553 & 3,9 & 2156,7 & 1,493 & 826 \\
\hline $\begin{array}{l}\text { Електронне } \\
\text { обладнання }\end{array}$ & 296 & 3,2 & 947,2 & 1,603 & 474 \\
\hline $\begin{array}{l}\text { Навігаційне } \\
\text { обладнання }\end{array}$ & 356 & 3,2 & 1139,2 & 2,235 & 796 \\
\hline Кабіна екіпажу & 334 & 2,1 & 701,4 & 3,03 & 1012 \\
\hline Загальне обладнання & 550 & 15,6 & 8580 & 2,364 & 1300 \\
\hline $\begin{array}{c}\text { Обладнання } \\
\text { пасаж. салону }\end{array}$ & 2340 & 13,6 & 31824 & 2,35 & 5499 \\
\hline $\begin{array}{c}\text { Маса обладнання } \\
\text { сумарна }\end{array}$ & 5229,44 & & 47184,16 & & 11400 \\
\hline \multirow{4}{*}{$\begin{array}{c}\text { Порожній літак без } \\
\text { екіпажу, палива, } \\
\text { корисного } \\
\text { навантаження, сума }\end{array}$} & \multirow{4}{*}{19966,23} & & \multirow{4}{*}{210669,5} & & 55602 \\
\hline & & & & 1,862 & 931 \\
\hline & & & & 1,872 & 562 \\
\hline & & & & 1,493 & 826 \\
\hline \multicolumn{6}{|c|}{ Паливо } \\
\hline Консоль ліва & 2461,63 & 12,195 & 30019,58 & 4,12 & 10142 \\
\hline Консоль права & 2461,63 & 12,195 & 30019,58 & 4,12 & 10142 \\
\hline Центроплан & 955,43 & 10,156 & 9703,347 & 4,35 & 4156 \\
\hline Маса палива & 6188,094 & & 73515,68 & 4,1 & 25371 \\
\hline $\begin{array}{c}\text { Комерційне } \\
\text { навантаження та } \\
\text { екіпаж } \\
\end{array}$ & 8900 & 13,434 & 119562,6 & 2,35 & 20915 \\
\hline $\begin{array}{c}\text { 3літна маса, шасі } \\
\text { випущено }\end{array}$ & 35054 & & 403747,7 & & 122172 \\
\hline Координата ц.м & $x_{u \cdot m}$ & 11,518 & $y_{u . M}$ & 3,485 & \\
\hline Центрування & $\bar{x}_{u \cdot M}$ & 0,274 & $\bar{y}_{u \cdot m}$ & $-0,181$ & \\
\hline
\end{tabular}


Таблиця 3 - Характерні випадки завантаження літака

\begin{tabular}{|c|c|c|c|c|c|c|c|}
\hline $\begin{array}{c}\text { № } \\
\text { п.п. }\end{array}$ & $\begin{array}{c}\text { Корисне } \\
\text { навантажен } \\
\text { ня, пас. }\end{array}$ & Шасі & Паливо & $\begin{array}{c}\mathrm{x}_{\text {ц.т., }} \\
\text { мм }\end{array}$ & $\mathrm{x}_{\text {ц.т. }}$ & $\mathrm{y}_{\text {ц.т. }}, \mathrm{Mм}$ & $\mathrm{y}_{\text {ц.т. }}$ \\
\hline 1 & $\begin{array}{c}\text { Пасажирів } \\
\text { немає }\end{array}$ & випущено & нет & 10551 & 0,31 & 3,485 & $-0,2058$ \\
\hline 2 & 73 & випущено & $100 \%$ & 11517 & 0,41 & 3,435 & $-0,1925$ \\
\hline 3 & 99 & прибрано & $100 \%$ & 11511 & 0,25 & 3,455 & $-0,1476$ \\
\hline 4 & 85 & прибрано & $10 \%$ & 11440 & 0,22 & 3,65 & $-0,1471$ \\
\hline 5 & 90 & випущено & $10 \%$ & 11448 & 0,4 & 3,59 & $-0,15$ \\
\hline
\end{tabular}

Літак $є$ статично стійкім і таким що керується в розглянутому діапазоні випадків завантаження літака. Різниця відносних координат аеродинамічного фокусу і граничного заднього центрування складає 0,0525.

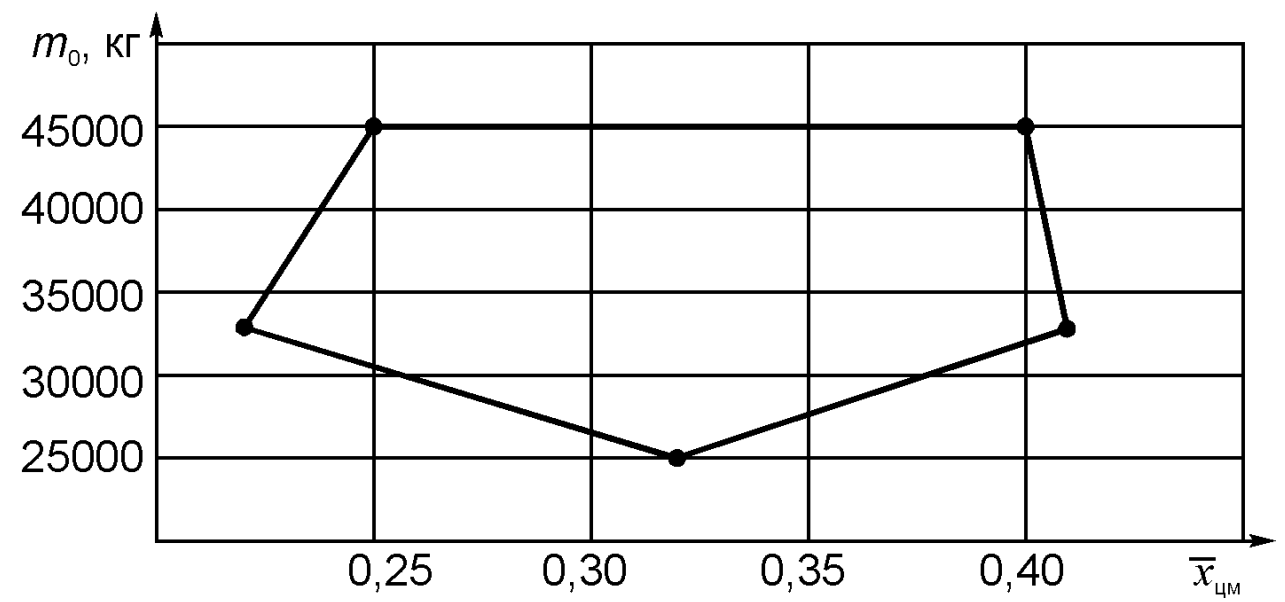

Рисунок 13 - Діапазон центрівок

\section{Висновки}

Запропоновано метод попереднього проектування регіональних пасажирських літаків.

Актуальність робіт зі створення ряду нових пасажирських літаків підтверджена постановою КМУ в межах «Державної комплексної програми розвитку авіаційної промисловості України на період до 2020 року».

Метод проектування апробовано з використанням параметрів літаків ДП «Антонов» ряду Ан-148. Порівняння результатів розрахунків за методом, що пропонується, із параметрами існуючих літаків ряду Ан-148 свідчить про коректність розробленого методу й результатів розрахунків.

Літак характеризується сучасною аеродинамічною конфігурацією, застосуванням економічних двигунів. Сучасне пілотажно-навігаційне обладнання й обладнання радіозв'язку, застосування багатофункціональних індикаторів, електродистанційної системи керування польотом дають змогу застосовувати його на будь-яких повітряних трасах, у простих і складних 
метеоумовах, удень і вночі, також на маршрутах з високою інтенсивністю польотів при високому рівні комфорту екіпажу.

Комфорт пасажирів забезпечується на рівні середньостатистичного комфорту на магістральних літаках і досягається раціональним компонуванням та складом сервісних приміщень, глибокою ергономічною оптимізацією загального й індивідуального простору пасажирського салону. Літак повністю відповідає нормам льотної придатності АП-25.

Порівнянні з Ту-134 літак має:

- значно вищий рівень комфорту пасажирів (75 місць розташовано 3 відстанню між рядами 812 мм проти 76 місць з відстанню між рядами 750 мм);

- $\quad$ майже в 1,8 раза більшу максимальну дальність польоту (4240 км проти 2400 км) при практично однакової пасажиромісткості;

- $\quad$ значно меншу необхідну довжину 3ПС (1950 км проти 2500 км);

- у 1,55 раза меншу витрату палива за 1 год (1650 кг/год проти 2550 кг/год).

Високий технічний рівень, закладений при проектуванні літака, зокрема його аеродинамічна та масова досконалість, дав змогу спроектувати крило, площа якого в 1,46 раза менше площі крила літака Ту-134. Це, а також компонування з двигунами, розміщеними на пілонах під крилом, а не в хвостовій частині фрюзеляжу, дає змогу мінімізувати габаритні розміри літака, що зменшило на 27 \% необхідну для нього площу стоянки порівняно з Ту-134. Максимальну злітну масу літака вдалося знизити в порівнянні із Ту-134 на 8\%.

Основні переваги літака в порівнянно з аналогами, що експлуатуються в теперішній час, на світовому ринку (ERJ 170LR, ERJ 175LR, CRJ 700LR, CRJ 705ER):

- можливість експлуатації на аеродромах з малопідготовленими 3ПС;

- $\quad$ автономність експлуатації (наявність дверей-трапа);

- $\quad$ висока захищеність двигунів від пошкодження сторонніми предметами;

- $\quad$ високий рівень комфорту для пасажирів (на рівні магістральних літаків);

- великі багажні полиці (на рівні магістральних літаків);

- низька ціна порівняно з ERJ170/175 і CRJ700/705;

- низькі прямі експлуатаційні витрати порівняно з ERJ170/175 і CRJ700/705;

- висока ефективність експлуатації порівняно з ERJ170/175 і CRJ700/705.

Результати розрахунків свідчать про те, що всі основні технічні характеристики літака $€$ кращими від характеристик літаків-аналогів фрірм Embraer i Bombardier. Крім того, літак має багато переваг, таких як можливість експлуатації на аеродромах з малопідготовленими і ґрунтовими ЗПС, наявність дверей-трапа, висока захищеність двигунів від пошкодження сторонніми предметами, високий рівень комфорту пасажирів і великі багажні полиці, висока ефективність експлуатації. Ці переваги забезпечують високий рівень конкурентоспроможності літака на світовому ринку. 


\section{Список літератури}

1. Г. А. Кривов, В. А.Матвиенко, А. А.Щербак, Т. Н. Щедрина Гражданское самолетостроение в начале XXI столетия. Деятельность ведущих мирових производителей. Киев: КИТ, 2008. - 168 с.

2. Пядушкин М. Перевозчики удивили авиастроителей // Авиатранспортное обозрение. - 2007. - №78. - С 13-15.

3. Ian Goold. Bombardier Sees Need For 11,000 20- To 149-Seaters Over 20 Years // Aviation International News, Farnborough International Air Show Daily. 2006. - 19.07. - P.5.

4. Кива, Д.С. Научные основы интегрированного проектирования самолетов транспортной категории [Текст] : монография. В 3 ч. / Д. С. Кива, А. Г. Гребеников. - Харьков: ХАИ, 2014. - Ч. 2. - 326 с.

5. Проектирование самолетов [Текст] : учеб. для вузов / С. М. Егер, В. Ф. Мишин, Н. К. Лисейцев и др.; под ред. С. М. Егера. - 3-е изд., перераб. и доп. - М.: Машиностроение, 1983. - 616 с.

6. Шейнин, В. М. Весовое проектирование и эфрфективность пассажирских самолетов [Текст] : справочник / В. М. Шейнин , В. И. Козловский. - 2-е изд., перераб. и доп. - М. : Машиностроение, 1984. - 552 с.

7. Информационные технологии в наукоемком машиностроении: Компьютерное обеспечение индустриального бизнеса [Текст] / под. общ. ред. А. Г. Братухина. - Киев: Техніка, 2001. - 728 с.

8. Холявко, В. И. Расчет аэродинамических характеристик самолета. [Текст] : учеб. пособие / В. И. Холявко. - Харьков: ХАИ, 1991. - Ч. 1 - 72 с.

9. Торенбик, Э. Проектирование дозвуковых самолетов [Текст] : пер. с англ. / Е.П. Голубков. - М. : Машиностроение, 1983. - 648 с.

10. Балабуєв П. В., Основи загального проектування літаків 3 газотурбінними двигунами [Текст]: навч. посіб. / П. В. Балабуєв, С. А. Бичков, О. Г. Гребеніков та ін. - Харків: XАI, 2015. - 815 с.

11. Самолет Ан-140. Стандартная спецификация: учеб. / П.В. Балабуев, А.Г. Гребеников, П.А. Клюев и др. - Харьков: ХАИ, 2004, 2004. - 260 с.

12. Самолет Ан-74 ТК-300. Стандартная спецификация: учеб. / А.Г. Гребеников, П.А. Клюев, В.Н. Король и др. - Харьков: ХАИ, 2004. - 277 с.

13. Стандартная спецификация на тип самолета (вертолета): учеб. / А.Г. Гребеников, П.А. Клюев, В.Н. Король и др. - Харьков: ХАИ, 2004. - 336 с.

14. Нормы летной годности самолетов транспортной категории (АП-25). М.: МАК, $2009-322$ c.

\section{References}

1. G. A. Krivov, V. A.Matvienko, A. A.Shherbak, T. N. Shhedrina Grazhdanskoe samoletostroenie $v$ nachale XXI stoletija. Dejatel'nost' vedushhih mirovih proizvoditelej. Kiev: KIT, 2008. - $168 \mathrm{~s}$.

2. Pjadushkin M. Perevozchiki udivili aviastroitelej // Aviatransportnoe obozrenie. - 2007. - №78. - S 13-15. 
3. Ian Goold. Bombardier Sees Need For 11,000 20- To 149-Seaters Over 20 Years // Aviation International News, Farnborough International Air Show Daily. 2006. - 19.07. - P.5.

4. Kiva, D.S. Nauchnye osnovy integrirovannogo proektirovanija samoletov transportnoj kategorii [Tekst] : monografija. V 3 ch. / D. S. Kiva, A. G. Grebenikov. Har'kov: HAl, 2014. - Ch. 2. - 326 s.

5. Proektirovanie samoletov [Tekst] : ucheb. dlja vuzov / S. M. Eger, V. F. Mishin, N. K. Lisejcev i dr.; pod red. S. M. Egera. - 3-e izd., pererab. i dop. - M.: Mashinostroenie, 1983. - $616 \mathrm{~s}$.

6. Shejnin, V. M. Vesovoe proektirovanie i jeffektivnost' passazhirskih samoletov [Tekst] : spravochnik / V. M. Shejnin , V. I. Kozlovskij. - 2-e izd., pererab. i dop. - M. : Mashinostroenie, 1984. - 552 s.

7. Informacionnye tehnologii v naukoemkom mashinostroenii: Komp'juternoe obespechenie industrial'nogo biznesa [Tekst] / pod. obshh. red. A. G. Bratuhina. Kiev: Tehnika, 2001. - 728 s.

8. Holjavko, V. I. Raschet ajerodinamicheskih harakteristik samoleta. [Tekst] : ucheb. posobie / V. I. Holjavko. - Har'kov: HAI, 1991. - Ch. 1 - 72 s.

9. Torenbik, Je. Proektirovanie dozvukovyh samoletov [Tekst] : per. s angl. I E.P. Golubkov. - M. : Mashinostroenie, 1983. - 648 s.

10. Balabuev P. V., Osnovi zagal'nogo proektuvannja litakiv z gazoturbinnimi dvigunami [Tekst]: navch. posib. / P. V. Balabuev, S. A. Bichkov, O. G. Grebenikov ta in. - Harkiv: HAI, 2015. - $815 \mathrm{~s}$.

11. Samolet An-140. Standartnaja specifikacija: ucheb. / P.V. Balabuev, A.G. Grebenikov, P.A. Kljuev i dr. - - Har'kov: HAI, 2004 - 260 s.

12. Samolet An-74 TK-300. Standartnaja specifikacija: ucheb. / A.G. Grebenikov, P.A. Kljuev, V.N. Korol' i dr. - Har'kov: HAI, 2004. - 277 s.

13. Standartnaja specifikacija na tip samoleta (vertoleta): ucheb. / A.G. Grebenikov, P.A. Kljuev, V.N. Korol' i dr. - Har'kov: HAI, 2004. - 336 s.

14. Normy letnoj godnosti samoletov transportnoj kategorii (AP-25). - M.: MAK, 2009 - 322 s.

Надійшла до редакції 10.06.2019, розглянута на редколегії 12.06.2019

\section{Метод общего проектирования региональных пассажирских самолетов}

Предложен метод общего проектирования региональных пассажирских самолетов предназначенных для перевозки пассажиров, багажа, почты и грузов на внутренних и международных авиалиниях с возможность эксплуатации на аэродромах с искусственным покрытием и подготовленных грунтовых взлетнопосадочных полосах. Самолет разработан для замены устаревшего пассажирского самолета Ту-134 в парке авиакомпаний СНГ и других стран. Разработана концепция создания самолета с применением систем интегрированного проектирования. Учтено влияние параметров самолета на 
аэродинамические и массовые характеристики, при условии обеспечения требований к компоновке и безопасности полетов. Определен диапазон изменения параметров модификаций самолета. Метод апробирован путем сравнения полученных параметров с параметрами региональных пассажирских самолетов ГП «Антонов».

Самолет характеризуется современной аэродинамической конфигурацией, применением экономичных двигателей. Современное пилотажно-навигационное оборудование и оборудование радиосвязи, применение многофункциональных индикаторов, электро-дистанционной системы управления полетом позволяют применять самолет на любых воздушных трассах, в простых и сложных метеоусловиях, днем и ночью, а также на маршрутах с высокой интенсивностью полетов при высоком уровне комфорта пассажиров и экипажа.

Комфорт пассажиров - на уровне среднестатистического комфрорта на магистральных самолетах, что обеспечивается рациональной компоновкой и составом сервисных помещений, глубокой эргономической оптимизацией общего и индивидуального пространства пассажирского салона. Самолет полностью соответствует нормам летной годности АП-25.

Основные технические характеристики самолета сопоставимы с характеристиками самолетов-аналогов фрирм Embraer и Bombardier. Кроме того, самолет имеет ряд преимуществ: возможность эксплуатации на аэродромах с малоподготовленными и грунтовыми ВПП, наличие двери-трапа, высокая защищенность двигателей от повреждения посторонними предметами, высокий уровень комфорта пассажиров и большие багажные полки, высокая эффрективность эксплуатации. Эти преимущества обеспечивают высокий уровень конкурентоспособности самолета на мировом рынке

Ключевые слова: самолет, проектирование, общий вид, компоновка, мастергеометрия, фрюзеляж, расчет массы, аэродинамическое качество, транспортная эффрективность, параметрическая модель.

\section{Regional passenger airplanes general design method}

A method of general design of regional passenger planes for transportation of passengers, baggage, mail and cargo on domestic and international airlines with the possibility of operating on airfields with concrete and prepared unpaved runways is proposed. Airplane is designed to replace the outdated Tu-134 passenger aircraft in the fleet of airlines of the CIS and other countries. The concept of creating an aircraft using integrated design systems has been developed. The effect of the aircraft parameters on the aerodynamic and mass characteristics was taken into account, subject to the requirements for layout and flight safety. The range of variation of the aircraft modifications parameters has been determined. The method has been tested by comparing the obtained parameters with the regional passenger aircraft of the Antonov State Enterprise. 
The aircraft features a modern aerodynamic configuration and efficient engines. Modern flight and navigation equipment and radio communication equipment, the use of multifunctional indicators, electrical distant flight control system allowing them to be used on any airways, in simple and complex meteorological conditions, day and night, and on routes with high flight intensity at high comfort level of passengers and crew.

Passenger comfort is provided at the average level of long-haul aircraft, and is achieved by a rational layout and composition of service rooms, deep ergonomic optimization of the overall and individual space of the passenger compartment. The aircraft fully complies with the AP-25 airworthiness standards.

The main technical characteristics of the aircraft are comparable to the characteristics of the analogue aircraft of Embraer and Bombardier companies. In addition, the aircraft has several advantages, such as the ability to operate on aerodromes with poorly prepared and unpaved runways, the presence of a doorramp, high engine safety from damage by foreign objects, a high level of passenger comfort and large luggage racks, high efficiency of operation; high level of competitiveness in the global market

Keywords: aircraft, design, general view, layout, master geometry, fuselage, mass calculation, aerodynamic quality, transport efficiency, parametric model.

\section{Відомості про авторів}

Гребеніков Олександр Григорович - зав. каф.103 Національного аерокосмічного університету ім. М.Є. Жуковського «XAI». ORCID: 0000-00021509-0665

Донець Олександр Дмитрович - Президент ДП «АНТОНОВ», м. Київ.

Трубаєв Сергій Васильович - доц. каф.103 Національного аерокосмічного університету ім. М.Є. Жуковського «XАІ».

Чумак Антон Сергійович - ст. викл. каф.103 Національного аерокосмічного університету ім. М.Є. Жуковського «XAl». ORCID 0000-00032913-7038 